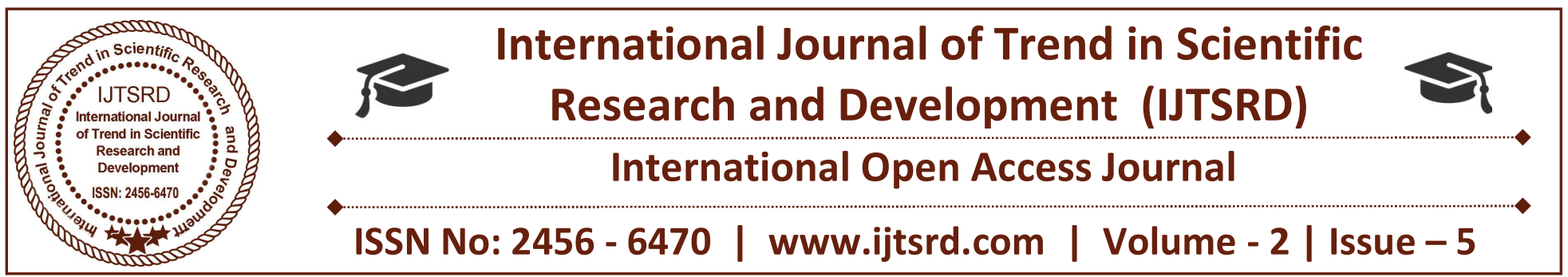

\title{
Effect of IFRS on Value Relevance of Accounting Information: Evidence from Quoted Manufacturing Firms in Nigeria
}

\author{
Ezejiofor, Raymond Asika (PhD) \\ Department of Accountancy, Nnamdi Azikiwe University, P. M. B., \\ Awka, Nigeria, West Africa
}

\begin{abstract}
This study evaluated the extent to which value relevance of financial information in Nigerian manufacturing firms has improved after the implementation of International Financial Reporting Standards (IFRS). Specifically, the study intended to:

recommends among other things that the accounting information for book value per share should be communicated to the investing public; and such information should be of high quality to avoid negative consequences on the part of investors.
\end{abstract} Ascertain the extent the adoption of IFRS has significantly improved the book value per share of manufacturing companies in Nigeria; Determine the extent the adoption of IFRS has significantly improved the Earnings Per Share of manufacturing companies in Nigeria and Examine the extent the adoption of IFRS has significantly improved the cash flow of manufacturing companies in Nigeria. Ex-post facto research design was adopted for the study. A sample of 54 manufacturing companies was randomly selected from manufacturing companies quoted on the Nigerian Stock Exchange for the periods of 20082015. Data for the study were obtained from the annual reports and accounts of the sampled companies. Specifically, a modified price model for detecting value relevance of accounting data for two different periods was employed. Regression Analysis and Chow test statistical tools were used to analyze and validate the data with aid of SPSS version 20.0. The study found that the adoption of IFRS has improved the book value per share, market share price, Earnings Per Share and cash flow of manufacturing companies in Nigeria. The implication of findings is that the value relevance of accounting information of manufacturing companies is more sensitive during Post-IFRS era than the Pre-IFRS era. The findings also imply that the book value per share, market price, earnings and cash flow have become informative to equity investors in determining the value of firms following IFRS adoption. The study

KEYWORD: Value relevance, information, manufacturing companies

accounting

\section{INTRODUCTION}

Value relevance research is being motivated by the fact that listed firms use financial statements as one of the major medium of communication with their shareholders and public at large. Markets usually depend on financial reports prepared by the Management of such firms (Khanna, 2014). Barth, Cram and Nelson, (2001) believe that for making the financial reporting to be effective, information contained in the financial reports should be relevant and reliable. Information is considered to be relevant when it influences the users' decisions to form predictions or help in confirming or correcting the past evaluations, while, it is considered reliable if it can be depended upon to faithfully represent the transactions or events that it aims to represent without any undue error or bias (FASB, 1978). Bello (2009), believes that accounting is an information infrastructure used by economic units to achieve various economic decisions.

Corporate organizations use accounting to communicate to all stakeholders about their operating performance and position at a particular time period. The value of a firm is based on what the market perceives about its performance, and accounting 
disclosures provide the essential information so as to form the basis of such perception. Many studies have examined the value relevance of earnings per share (EPS), book value of equity per share (BVPS), and cash flows. Such studies have reported that earnings and book values have significant information content for equity valuation of a firm (Holthousen and Watts, 2001; Choi and Jang, 2006; Kwon, 2009).

A review of international reports published since 1970 examining the purpose of accounting information and content, indicates that the focus is on the needs of external users and the decision usefulness of accounting information. In the last decade, accounting literature has focused increasingly on examining the value relevance of accounting information (Adaramola \& Oyerinde, 2014). The dynamic nature of the environment in which accounting operates led to the development of different methods of wealthcreation in each emerged environment through time. These environments according to Lamberg (2004) include agriculture, industrial and information era; each wealth-creation method was served with appropriate accounting model in order to produce relevant accounting information for economic decisions. Sibel, (2013) opine that accounting information contained in financial statements is expected to be useful for decision makers. In order to provide this, financial statements should meet some basic characteristics. "If financial information is to be useful, it must be relevant and faithfully represent what it purports to represent. The usefulness of financial information is enhanced if it is comparable, verifiable, timely and understandable" (CFFR, 2010).

Inherent in the profession of accounting are rules and principles that give room for manipulations and designs by professional accountants. Hence, given the required skill and accounting acumen, two accountants could present two different profit figures from the same records and none would be considered to have erred in so far as he considers some underlying concepts in the preparation of his accounts. Advocates of fair value accounting see the key motivation in reporting all assets in the balance sheet at fair value because it is more current and perhaps more relevant (Cunningham \& Harris, 2006). However, accounting traditionally measures most assets using historical cost because it is considered reliable. This serves as the basis of annual depreciation of the historic value of an asset as it is justified by its consistent burdening of income of accounting periods with the supposed equivalent contribution of the depreciated asset to the generation of such incomes. This tradition is faulted both in basis and methods. Depreciation methods are numerous and also produce different depreciation figures. This and several other examples dominate the principle and practices of accounting. The exploitation of the loopholes created by the accounting rules to generate undeserved and unwarranted benefits is referred to as designed accounting or creative accounting, also termed macro-manipulation, income smoothing, earnings management, earnings smoothing, financial engineering cosmetic accounting or window dressing (Belkaoui, 2004). Designed accounting is defined as "the opportunistically used discretion over accounting numbers with intention to mislead users of the information".

Financial reporting by companies is effected via the preparation and publication of financial statements. These financial statements are required to exhibit certain degree of quality in terms of their information contents. Maines and Wahlen (2006) and Belkaoui (2002) opine that accounting information contained in the financial reports should possess certain qualities as Crelevance, verifiability, understand ability, neutrality, timeliness, comparability, and completeness. When the financial reports disclose quality accounting information, Benston (2007) stated that the decision of the users (investors, management, government, employees, creditors, analysts) of the reports could as well be qualitative and informed. The users of the financial reports use the reports frequently in passing judgments on the viability of a company. Ghofar and Saraswati (2008) opined that investors in many cases are too dependent on the quality of accounting disclosure.

Applied faithfully, the harm caused by the strict adherence to accounting rules could have been restricted to the relevance and reliability of the figures it produces in terms of time value of money. By extension however, the loopholes created by these rules have been exploited by fiendish accountants to perpetrate fraud and this has taken a toll on the profession as it has manifested in an upsurge of accounting scandals across the globe thereby having implications for the public confidence in the profession.

The quality of information provided in financial reports determines the usefulness and reliance of such 
reports to users. Palea (2013) opines that financial information influences investors' behavior with respect to portfolio selection, which in turn affects security prices and therefore, the terms on which a firm obtains additional financing. Standard setters, regulators, and policy-makers all have a vital interest in the effect of financial reporting on the economy. This interest is due to the economic consequences associated with financial information. 'Value relevance is one of the measures used in determining accounting quality' (Adebimpe \& Ekwere 2015).

Nigerian Accounting Standards Board (NASB) is the first Federal agency statutorily responsible for the development and issuance of Statements of Accounting Standards (SAS) used in the preparation of financial statements in Nigeria. The NASB initially derived its powers from Section 335(1) of Companies and Allied Matters Act 1990 until the Nigerian Accounting Standards Board Act No. 22 of 2003 was enacted.

The development and adoption of the IFRS (International Financial reporting standards) is a major development across the Globe arises from the need for better comparability and relevance of accounting statements across the Globe has changed the face of financial reporting within and amongst countries (Nassar, Uwuigbe \& Abuwa, 2014). The use of IFRS in preparing financial statements globally is maturing. This is not surprising given the pains associated with the low quality financial reports which witnessed an unprecedented growth in the recent past.

The move towards a unified set of accounting standards could be traced to 1993 , when about 16 professional accounting bodies from Australia, Canada, France, Germany, Japan, Mexico, the Netherlands, the United Kingdom, and the United States established the International Accounting Standards Committee (IASC), which was later changed to the International Accounting Standards Board (IASB) in 2001(Herbart \& Isegba, Ohaneta and Anyahara, 2013; Isennulla \& Adeyemi, 2013; Barth, Landsman \& Lang, 2007).

The primary goal of the IASB and its predecessor body, IASC is to evolve a globally acceptable set of high quality financial reporting standards (Okoye, 2014; Barth, Landsman and Lang, 2007). It was the primary duty of IASC to issue IASs, while the successor, the IASB issued the IFRS which included the adoption of the IASs already issued by the IASC (subsequent to amendment) (Oyedele, 2011; Barth, Langsman and Lang, 2007).

IFRS is a set of International Accounting Standard (IAS) that state how particular transactions and events should be reported in the financial statement of the companies. The standard which replace the old IAS are issued by the International Accounting Standard Board (IASB) for the purpose of making comparison as easy as possible. IFRS remains as a standard with high quality accounting reporting framework. Thus, the users of financial statements can easily compare the entity's financial information between countries in different parts of the world. Implications of adopting IFRS means adopting a global financial reporting language that would create a company globally understood financial statement (Fasina \& Adegbite, 2014). To achieve full adoption of the IFRS in Nigeria, the NASB (now financial Reporting Council (FRC) established by FRC of Nigeria Act No 6, 2011) inaugurated a Roadmap Committee of Stakeholders on the adoption (Okoye, 2014).

The demand for relevant accounting disclosures by users is increasing due to the rapid growth of business environments worldwide. Businesses continue to grow with more people participating in the stock market (Kasum, 2007) and comparing financial information between firms of different countries has become significant issue to investors (Tarca, 2004).

Studies have been conducted in Nigeria to ascertain the value relevance of accounting information (Adaramola \& Oyerinde, 2014, Abiodun, et al, 2012). But questions remain as to whether the relevance of accounting information has increased or decreased over time. Sami and Haiyan (2004) find that the explanatory power of earnings of stock return is very limited and consistent with the prior studies in US.

Gaston, Fernadez et al, 2004) find that accounting institutional environment has a stronger positive association with value relevance of accounting earnings than legal environment. Beijer, Dekimpe, Dutordoir, and Verbeeten, et al (2008) revealed a positive relationship between dividends, book value and earnings with stock market value. Habib and Elhamaney (2009); Perara and Thrikawala (2010) reveal a relationship between Accounting Information and Market Price per Share. Halonen, Parlovic and 
Pearson et al (2013); Mechelli and Cimini, et al (2014); Yusuf and Nor Asma et al (2015) show that accounting information has the ability to capture information that affects equity values and that there is relationship between accounting numbers and share prices in Nigerian Stock Market.

On other hand, Ortega (2006); Aleksanyan (2007); Omaima, Peter, Gianluigi and David (2008); indicated that after controlling factors such as asset size and profitability, mandatory disclosure has a highly significant but negative relationship with firm value. Olga and Veltri, et al, (2012) findings shows that earnings is more value relevant than book values by extension that, the information contained in the income statements, as proxied by the earnings, dictates more of the corporate values of firms in Nigeria than the information contained in the balance sheet, as ably proxied by the book values (Uthman and Abdul-Baki, et al, 2014).

There is a limited study on Nigerian manufacturing companies in relation to International financial reporting standard, In addition, the prior studies results were inconsistent, of which consist of both negative and positive views and this might be as a result of common methodology being used. This research is expected to contribute through the research literature and adding additional methodology in determining the effect of value relevance of accounting information (market price, book value of equity, earnings per share and cash flow) on the Nigerian manufacturing firms, coupled with the recent changes in the International Financial Reporting Standard across the globe.

\subsection{Objectives of the Study}

This study set out to determine whether value relevance of financial information in Nigerian manufacturing firms has improved after the implementation of International Financial Reporting Standards (IFRS). Specifically, the study intends to:

1. Ascertain the extent the adoption of IFRS has significantly improved the book value per share in determining market price of manufacturing companies in Nigeria.

2. Determine the extent the adoption of IFRS has significantly improved the Earnings Per Share in determining market price of manufacturing companies in Nigeria.

3. Evaluate the extent the adoption of IFRS has significantly improved the cash flow in determining market price of manufacturing companies in Nigeria.

\subsection{Formulation of Hypotheses (Null)}

1. Ho: The adoption of IFRS has not significantly improved the book value per share in determining market price of manufacturing companies in Nigeria.

2. $\mathrm{H}_{\mathrm{O}}$ : The adoption of IFRS has not significantly improved the Earnings Per Share in determining market price of manufacturing companies in Nigeria.

3. Ho: The adoption of IFRS has not significantly improved the cash flow in determining market price of manufacturing companies in Nigeria.

\section{REVIEW OF RELATED LITERATURE \\ 2.1 CONCEPTUAL FRAMEWORK \\ 2.1.1 The Origin of IFRS Adoption in Nigeria}

It is generally believed that accounting history can be traced to Luca Pacioli in 1494, however, the history of accounting dates back to period before the advent of the concept of money which is before Luca Pacioli Era (Jayeoba \& Ajibade, 2016). Although, the formal book keeping and accounting process was first documented by Luca Pacioli in 1494. The evidence of accounting's existence before the advent of the concept of money was supported by archaeologists and historians who discovered the oldest city of Jericho as a trade centre for salt. It was evidenced in this city that no complete accounting was there but the artifacts revealed remains of a temple priest taking inventory of the village livestock using tokens to keep track of the herd size and count the grain harvest (Mattessich, 1989). Through fossils and records discovered not only in Jericho but other parts of the world, it can be concluded that before men knew the concept of money, the process of stewardship was known.

The move for the adoption of IFRS in Nigeria started 2010 following the Federal Executive Council's approval of the road map for the adoption of the standards. This was followed with the enactment of Financial Regulation Council of Nigeria Act in 2011 which led to the transformation of the NASB to Financial Regulation Council (FRC). The FRC among other things is charged with the responsibility of implementing the roadmap for the adoption of IFRS in Nigeria. 
Sani and Umar (2014) stated that to allow for effective implementation of IFRS adoption in Nigeria, the former regulatory body in charge of monitoring the reporting system was in 2011 restructured from Nigerian Accounting Standards Board (NASB) to Financial Reporting Council of Nigeria (FRC). Financial Reporting Council of Nigeria is now the body corporate solely responsible for the issuance, monitoring and review of Accounting and Auditing Standards in Nigeria. The council is empowered under section 52(1) of the Act to adopt and keep up- to-date accounting and auditing standards, and ensure consistency between Standards issued under International Financial Reporting Standards as provided under Part VII of FRC Act 2011 which dealt with review and monitoring of standards. The major developments that facilitated the enactment of FRCN Act No 6, 2011 was the Federal Executive Council approval to adopt IFRS as the reporting framework for publicly listed entities by 2012 in Nigeria (Latifat, 2015).

The strategic attribute is a major material for IFRS adoption, Nigeria is situated in Western Africa, bordering the Gulf of Guinea, between Benin and Cameroon. It has an estimated population of over 175 million; it has the largest market for goods and services in Africa. Its gross domestic product (purchasing power parity) is $\$ 444.3$ billion (2012 est) Fact book (2014). It has an active Nigerian Stock Exchange which has 257 listed companies with a combined market capitalization of Nigerian Naira (NGN) 18.949 trillion (about US\$115.68 billion) (NSE, 2014). The practice of Accountancy worldwide is guided by sets of guidelines and rules. The rules and guidelines are compiled into accounting standards. They are statements of principle that discusses the accounting treatment and disclosure of a particular item or group of items. Before 2012, the Statements of Accounting Standards was used in accounting practice in Nigeria. The local accounting standards are issued in Nigeria by the Nigerian Accounting Standard Board (NASB) till 2011. NASB was established in 1982 as a private sector initiative and became a government agency in 1992, reporting to the Federal Minister of Commerce. The NASB was given a legal backing by its inclusion in Section 335(1) of the Companies and Allied Matters Act of 1990 which mandates all companies to prepare financial statements that complies with the Statement of Accounting Standards (SAS) as developed and issued by NASB from time to time. The NASB in
2003 was given the full autonomy as a legal entity with the enactment of the NASB Act of 2003. The Nigerian Accounting Standards Board Act of 2003 provided the legal framework under which NASB set accounting standards. The primary functions as defined in the Act of 10 July 2003 were to develop, publish and update Statements of Accounting Standards to be followed by companies when they prepare their financial statement, and to promote and enforce compliance with the standards. In the wake of financial crises in late 1990s, the international community emphasized the major role that the observance of international standards and codes of best practices in order to strengthen global financial systems. The international community called for the preparation of Reports on the Observance of Standards and Codes (ROSC), an assessment of the degree to which an economy observes internationally recognized standards and codes. It was observed by the World Bank about Nigeria, that the NASB lacks the financial and human resources as well as the infrastructure for monitoring and enforcing compliance with its standards. The ROSC team observed from a review of published financial statements that there are compliance gaps between the SAS and actual practice (Adebimpe \& Ekwere, 2015).

The ROSC team recommended the creation of a new independent oversight body called the Financial Reporting Council which would monitor and enforce accounting and auditing requirements. This was signed into law on 20 July 2011 . The FRC is a unified independent regulatory body for accounting, auditing, actuarial, valuation and corporate governance. It is expected that more meaningful and decision enhancing information can now be arrived at from financial statements issued in Nigeria because accounting, actuarial, valuation and auditing standards, used in the preparation of these statements, shall be issued and regulated by this Financial Reporting Council (Adebimpe \& Ekwere, 2015).

Although the Nigerian Statements of Accounting Standards (SAS) are similar to IFRS in certain respects, many differences exist. SAS promulgated by NASB were largely based on past IAS promulgated by IASC. Due to the increasing complexity of financial reporting requirements, some of the original IASs were reviewed resulting in their amendment or withdrawal. Adebimpe and Ekwere (2015) stated that the SASs were not reviewed or updated with the IASs/IFRSs. The significant disparities between the 
Nigerian SASs and IFRSs have resulted in the SAS being regarded as outdated and incomplete as an authoritative and internationally accepted guide to the preparation of financial statements. This has significantly diminished the degree of confidence on Nigerian Standards especially by international users of financial statements produced in Nigeria. The Nigerian SAS seems to be sub-standard in that the requirement of many SASs accords substantially with the requirement of its equivalent IFRSs that had been withdrawn or outdated. Some SASs does not have equivalent IASs/IFRSs. For example SAS 1 (Disclosure of Accounting Policies) accords substantially with IAS 1 (Disclosure of Accounting Policies) which had been reformatted in 1994. Also, SAS 2 (Information to be disclosed in Financial Statements) agrees with IAS 5 (Information to Be Disclosed in Financial Statements) originally issued October 1976, which has been superseded by IAS 1, Presentation of Financial Statements in 1997. Another example is SAS 9 (Accounting Depreciation) which is in accord with IAS 4 (Depreciation Accounting) which has been withdrawn in 1999. There are sixteen (16) IFRSs/IASs with no equivalent SASs: IFRS 1 (First time Adoption of International Financial Reporting Standards), IFRS 2 (Share-based Payment), IFRS 5 (Non-current Assets Held for Sale and Discontinued Operations), IFRS 7 (Financial Instruments: Disclosures), IFRS 9 (Financial Instruments), IFRS 13 (Fair Value Measurement), IFRS 14 Regulatory Deferral Accounts, IFRS 15 Revenue from contracts with customers, IAS 18 (Revenue), IAS 20 (Accounting for Government Grants and Disclosure of Government Assistance), IAS 23 (Borrowing Costs), IAS 24 (Related Party Disclosures), IAS 29 (Financial Reporting in Hyperinflationary Economies), IAS 32 (Financial Instruments: Presentation), IAS 36 (Impairment of Assets) and IAS 41( Agriculture). Also SICs (1-33) and IFRICs (1-21) have no equivalent Nigerian interpretations (Adebimpe \& Ekwere, 2015).

Based on the premise of NASB to promote general acceptable published financial reports and high quality accounting standards that are consistent with international practices, inaugurated a Stakeholders' Committee on the Roadmap to the Adoption of IFRS in Nigeria on October 22, 2009. In July 2010, the Nigerian Federal Executive Council approved the Roadmap to the Adoption of IFRS in Nigeria (NASB, 2010). It was reiterated in the report that, that it will be in the interest of the Nigerian economy for reporting entities in Nigeria to adopt globally accepted, high-quality accounting standards by fully converging Nigerian national accounting standards with International Financial Reporting Standards (IFRS) by following a Phased Transition effective January 1, 2012. It is a three phase transition programme. Phase 1 relates to the publicly listed entities and significant public interest entities. They are to prepare their financial statements using applicable IFRS by January 1, 2012. Phase 2 relates to other public interest entities, which are expected to mandatorily adopt IFRS, for statutory purposes, by January 1, 2013. Phase 3 relates to Small and Medium-Sized Entities (SMEs) which are expected to mandatorily adopt IFRS for SMEs by January 1, 2014.

\section{Reason for IFRS Adoption in Nigeria}

The story of the tower of Babel signified that anything can be achieved when there is uniformity in language. In this same vein, the evolution of accounting (seen as the language of business) strives towards "a uniform language" which is the adoption of International Financial Reporting Standards in many countries of the world. Regulation of accounting information is aimed at ensuring that users of financial statement receive a minimum amount of information that will enable them make meaningful decisions regarding their interest in a reporting entity (Jayeoba \& Ajibade, 2016). Accounting standards, as explained by Okaro (2002), are authoritative statements aimed at narrowing the areas of differences and varieties in accounting practice. Accounting standards are not only seen as important regulatory devices but also act as a unifying template connecting the interest of the users of financial statement.

It will not be totally wrong to conclude that the adoption of IFRS and the enactment of the Financial Reporting Council Act, 2011 were triggered by the nation's sense of belonging since IFRS has already been embraced by over 122 countries. This sense of belonging and not feeling left out can be seen as positive when the growth and development of the nation is at stake. According to Asein (2011), it was expedient and in the best interest of the nation to raise and benchmark the quality of its financial reporting on current global best practices by adopting IFRS in order to achieve its goal of becoming one of the twenty largest economies of the world by year 2020 (vision 20:2020 goals). It can be deduced from Obazee (2011), that the move towards adopting the 
IFRS was majorly triggered by the nation's objective to realize the full gains of cross border listing.

Since the 1960s, businesses have become more global and thus lost a significant part of their national identities. Nigeria's global players are reporting to global finance market, therefore it justifies the need to have global financial reporting benchmarks. Nigerian businesses are making more international transactions, cross border listing is now common place, accounting firms are beginning to follow their growing corporate clients into other countries in order to maintain services and governments are engaging in wide range reviews that recognize the importance of reassuring the markets and the public at large that corporate reporting and governance frameworks are sufficiently robust (Josiah, Okoye \& Adediran 2013). This rapid growth of international trade and internationalization of firms, developments of new communication technologies, and the emergence of international competitive forces have disturbed the financial environment largely. Under this global business scenario, the residents of the business community are badly in need of a common accounting language that should be spoken by all of them across the globe. A financial reporting system of global standard is a prerequisite for attracting foreign as well as present and prospective investors at home alike that should be achieved through convergence of accounting standards. It has been observed that people who invest overseas naturally want to be able to keep track of the financial health of the securities issuers. Convergence of accounting standards is seen as the only means to achieve this. Only by talking the same language one can understand each other across borders (Hati \& Rakshit, 2002; Nikhil, Bhagaban \&Alok, 2009).

Today, global commerce is increasingly polarized into Multi-National Corporations (MNCs) and national companies. Clearly, financial reporting is responding to this business dynamics by following in this direction. However, most national companies do not have foreign subsidiaries while their financial statements are mainly for tax assessment purposes and possibly to provide information to local banks in order to secure credit facilities; whereas, MNCs play in different jurisdictions through their subsidiaries which prepare financial reports in compliance with various local GAAPs. This entails huge conversion costs of their financial statements during consolidation. Since these MNCs often seek finance from various capital markets, comparability of financial reports was a huge problem leading, in many cases, to inefficient and sub-optimal investment decisions (Asein, 2011).

The development and adoption of the IFRS (International Financial reporting standards) is a major development across the Globe. The operation which arises from the need for better comparability and relevance of accounting statements across the Globe has changed the face of financial reporting within and amongst countries (Phang \& Mahzan, 2013). The use of IFRS in preparing financial statements globally is maturing. This is not surprising given the pains associated with the low quality financial reports which witnessed an unprecedented growth in the recent past (Isabel \& Mariela, 2009).

Globalization of capital market and internationalization has come to stay. The need for harmonization of financial statements and single set of consistent high quality financial reporting standard gained wide spread acceptance amongst policies makers, standard setters and preparers (Godfrey, Hodgson, Tarca, Hamilton, \& Holmes, 2010). The need for quality and uniformity in the preparation and presentation of financial statements gave birth to International Financial Reporting Standards (IFRS). Before the adoption in Nigeria, there was legal and regulatory framework of accounting in respect to preparation of financial report in Nigeria (Abdulkadir, 2013). The Company and Allied Matter Act (CAMA'90) prescribe some format and content of company financial statement disclosure requirements and auditing. It requires that the financial statement of all corporate organizations comply and adhere with the Statement of Accounting Standards (SAS) issued from time to time by the Nigerian Accounting Standard Board (NASB). This also requires that audit be carried out in accordance to with the General Auditing Standards. Therefore, the adoption of IFRS in Nigeria was launched in September, 2010 by the then Minister of Commerce and Industry. The adoption was organized in such that the entire stakeholders that prepare and present financial statement use it by the beginning of 2014. the adoption was made in such a way that all the first tier companies listed on the stock exchange and are of public interest use it by 2012, all other company of public interest but not first tier are to adopt in 2013 and all small and medium scale entity use it by January, 2014. Financial reporting standard exists because it serves as stewards to the owner of firms as ownership is divorced from controlling the activities 
of the business (Kasum, 2011; Phang \& Mahzan, 2013).

In addition, Internationalization and globalization of business has given reason for harmonized financial statement preparation and presentations (Isabel \& Mariela, 2009).Companies compete globally for limited resources, shareholders, potential investor and creditors as well as multinational enterprises are required to bear the cost of adopting financial statement that are prepared using national standards (Abdulkadir, 2013). It is expected that the move towards IFRS convergence will enhance capital market performance and ginger global business expansion in Nigeria. In the view of this development all corporate organization are expected to adopt and comply with IFRS in preparation and presentation of their financial statement (Oghoma \& Iyoha, 2006).

There is wide spread adoption and compliance by other country of the world. In a survey conducted by Manuel, (2008) on Spanish stock market, on how to hedge disclosures, today firms face several financial risks in their daily business activities due to global, international trading and transactions. One way to cope with this kind of risk is to use hedging because of its lower cost and good solution to solving risks in business entity (Leonard \& Jan, 2012). Additionally, Inwinkl (2010) conducted a survey on reclassifications of financial instruments in Nordic countries on the effect of reclassification amendments on Nordic banks financial statement. Quantitative survey was conducted on these Nordic banks and the results are as follows. $47 \%$ of sampled Nordic banks reclassified financial instrument in 2008 and $12 \%$ in 2009. All the banks increased their net profit as a result of reclassifying their financial instrument in 2008 and 2009. On the influence of IFRS implementation on business management, the finding of the study shows that there are positive effects from the adoption of the IFRS by Finnish companies (Jonna, 2009). IFRS are seen as a comprehensive information package where the management gets improved financial information easier for their decision making and judgement. In another research conducted by Jonna, (2009) mandatory IFRS contributes and improve business environment. The study was a survey report. He also found out that after mandatory IFRS adoption, the quality of information in accounting and business environment increased significantly more for mandatory adopters.
Conclusively, IFRS is a set of International Accounting Standard (IAS) that state how particular transactions and events should be reported in the financial statement of the companies. The standard which replace the old IAS are issued by the International Accounting Standard Board (IASB) for the purpose of making comparison as easy as possible. IFRS remains as a standard with high quality accounting reporting framework. Thus, the users of financial statements can easily compare the entity's financial information between countries in different parts of the world. Implications of adopting IFRS means adopting a global financial reporting language that would create a company globally understood financial statement (Oghoma \& Iyoha, 2006). The impact of inclusion of IFRS in schools and colleges curriculum will enable the potential accountants to be well trained before joining the accounting and auditing profession (Daske, Hail \& Leuz, 2006).

\section{Value Relevance of Accounting Information}

Value relevance of accounting information is defined as the ability of accounting numbers contained in the financial statements to explain the stock market measures (Beisland, 2009). In other words, value relevance tis being defined as the ability of information disclosed by financial statements to capture and summarize firm value. Value relevance can be measured through the statistical relations between information presented by financial statements and stock market values (returns).

A business enterprise specifically a company is a conscious, deliberate and purposeful creation for satisfying the domain of aspiration of the society at large. It is an independent and a separate legal entity (Tharmila \& Nimalathasan, 2013).

Vishnani and Shah, (2008) value relevance" implies ability of the financial information contained in the financial statements to explain the stock market measures. A value relevant variable is that data or amount in the financial statement that guide investors in their pricing of shares. Investment decision, therefore, centres on the association between stock returns or share price and accounting related information such as earnings, cash flows, book value of equity, firm's size.

Value relevance refers to the capacity of information to influence the decision making process of users. The users should be in a position to make predictions 
about the future with the available information. Information in order to be relevant should be made available to the user before it loses its capacity to influence decisions and therefore it should be apt and well-timed. Not only this, information should also be reliable that is free from bias and error (Swati, 2015).

The value relevance research provides evidence as to whether accounting numbers relate to corporate value in a predicted manner (Beaver 2002). The value relevance literature explains how well accounting amounts reflect information used by equity investors, and provides insights into questions of interest to standard setters.

The value relevance research is useful to the investors and also to the accounting standard setters. The objective of value relevance research is to find the company's financial statements are providing the investors with valid, adequate and reliable accounting information or not for decision making. It provides the statistical association measures whether investors actually use the information in question in setting prices or not.

Generally, investors are not in a situation to directly assess the performance of companies in which they intend to invest. They usually depend on financial statements prepared by the management of such organization. The primary purpose of financial statements is to provide information concerning the financial situation of the company, its operational results, any changes of control in the company and cash flow (Nirmala \& Florence, 2011).

The impact of financial statement information on capital markets indicators referred to as the value relevance studies and it is part of the market-based accounting stream. Information is considered 'value relevant' if stock price movements are associated with the release of such information (Utami \& Noraya, 2010).

The concept of value relevance refers to the strength of relationship between accounting variables and market value of equity of a firm. This is indicated from regression analysis and the earnings response coefficient of each accounting variable in the equation. The regression result can be used to measure another important concept of financial information, its timeliness. Timeliness means having information available to decision makers before it loses its capacity to influence decisions the value relevance of financial information can also be affected by how timely that information is (Kothari and Sloan, 1992; Colins, Maydew and Weiss, 1997; Lev and Zarowin, 1999). The coefficient of regression of market value on accounting numbers also indicates the timeliness of that accounting number.

A value relevance study is evaluation of the relationship between accounting information and capital market values (market values). Beaver (2002) indicated that the theoretical groundwork of value relevance studies adopting a measurement approach is a combination of valuation theory plus contextual accounting and financial reporting arguments (accounting theory) that allows the researcher to predict how accounting variables and other information relating to market value will behave. Holthausen and Watts (2001) suggest that value relevance studies use two different theories of accounting and standard setting to draw inferences: (i) "direct valuation" theory and (ii) "inputs-to equityvaluation" theory. Direct valuation theory proposes a link between accounting earnings and stock market value. In direct valuation theory, accounting earnings is intended to either measure or be combined with the equity market value changes or levels.

Value relevance is the "association between accounting amounts and security values" (Barth \& Beaver, 2000). The ability for financial reporting information to summarize and capture information that affects share values has been empirically tested as a statistical association between accounting and market values" and mapping from financial statements to "intrinsic" value (Aboody, Hughes \& Liu, 2002; Hellström, 2006; Tharmila \& Nimalathasan, 2013). Similarly, value relevance of financial information can be predictive and statistically measured through the relationship between stock market values or returns from the information reported by the financial statement (Barth, Cram, and Nelson, 2001), with the ability of the disclosed information in financial statement to capture and summarizes firm value (Be island, 2009; Kargin, 2013).

However, Beisl and (2009) reports that value relevance researches are associated with market efficiency as they can provide the relationship between accounting numbers and stock prices. In many studies, Ohlson model (1995) has been 
employed to explore associations between the market value of equities and main financial information disclosed variables, such as book value per share (as balance sheet) and earnings per share (as income statement), other comprehensive income and cash flows.

The International Accounting Standards Committee (IASC) 1989 reported the role of accounting information to be both confirmatory and predictive to market values and accounting numbers as well as interrelated to each other. Thus, the IASB in 2010 stated that, "Financial information needs to be predictive or forecasted to have predictive value; financial report with predictive value is used by users in making their predictions". Ebaid (2012) studied influence of accounting based methods on market returns and prices and their predictive values to be considered as the value relevance of accounting disclosures. Thus, generally book value is value relevant when it can determine stock prices (Kargin, 2013). Similarly, Vishnani and Shah (2008) report that, "Value relevance" denotes power of the financial information stated in the financial reports to explain the stock market price measures.

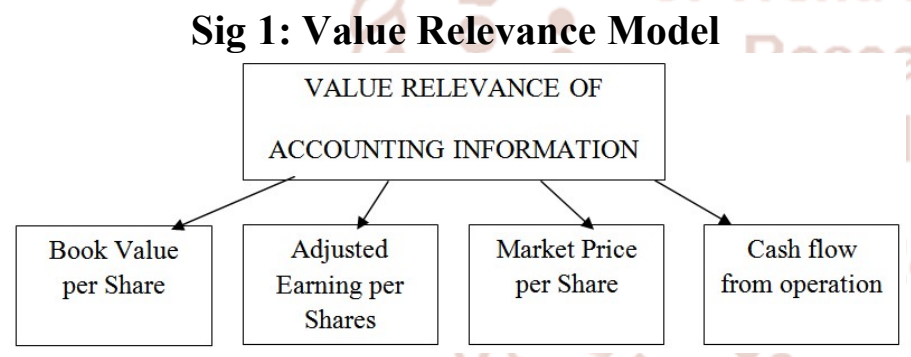

Source: Researcher's Value Relevance of Accounting Information Variables

\section{Accounting Information Variables}

According to Meyer (2007), "accounting plays a significant role within the concept of generating and communicating wealth of companies". Accounting data, such as earnings per share, is termed value relevant if it is significantly related to the dependent variable, which may be expressed by price, return or abnormal return (Gjerde, Knivsfla \& Saettem, 2007). Accounting information is any data or information obtained from the accounting system of a firm whether contained in a financial statement, a special report, or verbal statement (William, 1968). However, for the purpose of this research, accounting information refers to written information contained in a complete or partial financial report -financial position or comprehensive income or fund flow statement.

\section{Market Price per Share (MPS):}

Price is the arithmetic average of monthly average closing equity prices. Some authors may prefer to use share prices prevailing on the day immediately following the cross-section year. It could, however, be argued that share prices prevailing at any one day may contain random or temporary disturbances (Marris \& Singh, 1966). On the other hand, an average of monthly prices may be relatively free of temporary disturbances.

The share price of public traded company which is determined by the forces of market supply and demand is highly volatile due to its dependent on the expectations of the buyers and sellers (Menaje, 2012). O'Hara, Lazdowski, Moldovean and Samuelson (2000) find that earnings as well as dividend declared by firm are related to market prices of share. Irrespective of these accounting number that can be adopted to predict the market price, if this numbers contain some new information, reaction will always be expected in the market over the market price of share; this reaction evidence in share price is found to continually drift in the same direction as that of the initial information.

\section{Interpretation of Market Price Per Share vs Current Trading Price}

The market price per share and the current price at which the stock is being traded are not necessarily the same. The market price per share is also called the intrinsic value of a share of stock or the actual value based on the actual variables taken from the company's financial statements. The current trading price is based on investor buying and selling behavior. If investors are paying more than the intrinsic value, then the stock is overvalued. If investors are paying less than the intrinsic, then the stock is undervalued and is a good buy.

\section{Book value per share (BV):}

BV is the owners' equity over the number of shares in circulation. According to the theory (Ohlson, 1995), we expect a positive relationship between share prices and book value. Book value per share is determined by the researcher by dividing value of common equity by the number of shares outstanding for the respective periods. 
Furthermore, Ohlson (1995) and Feltham and Ohlson (1995) show that under certain condition, market value of a firm can be expressed as the weighted average of book value and earnings. This form the bases of the studies conducted on the value relevance of accounting numbers. Studies in this area of research have shown that the book value of equity in addition to earnings is associated with the market value of firms. While the fundamental role of earnings in value relevance is a long settled issue in accounting literature, this cannot be said of the book value of equity (Subramanyam \& Venkatachalam, 2000). The framework of the clean surplus valuation which is based on the residual income valuation model by Ohlson (1995) suggests that the book value of equity plays anchoring roles in valuation by representing the net stock of resources which the future earnings of firms depend and provides information on the liquidation or adaptation values of firms' net asset with poor financial performance (Barth, Beaver \& Landsman, 1998; Burgashler and Dichev, 1997). Springing from the notion that the book value represents stocks of resources that can be used to generate future earnings, Subramanyam and Venkatachalam (2000) posit that book value of equity is associated with market value due to the fact that it surrogates the current past earnings which are independently value relevant. Collins et al. (1997) find that omitting the book value of equity in a simple earnings capitalization model is tantamount to misspecification of model. This could induce a downward bias in the earnings coefficient for a loss making firms and upward bias for profit making firms.

Book value per share is just one of the methods for comparison in valuing of a company. Enterprise value, or firm value, market value, market capitalization, and other methods may be used in different circumstances or compared to one another for contrast. For example, enterprise value would look at the market value of the company's equity plus its debt, whereas book value per share only looks at the equity on the balance sheet. Conceptually, book value per share is similar to net worth, meaning it is assets minus debt, and may be looked at as though what would occur if operations were to cease. One must consider that the balance sheet may not reflect with certain accuracy, what would actually occur if a company did sell all of their assets

\section{Uses of book value per share}

The book value per share formula is used to calculate the per share value of a company based on its equity available to common shareholders. The term "book value" is a company's assets minus its liabilities and is sometimes referred to as stockholder's equity, owner's equity, shareholder's equity, or simply equity.

Common stockholder's equity, or owner's equity, can be found on the balance sheet for the company. In the absence of preferred shares, the total stockholder's equity is used.

Book Value per Share $=$ Total Common Shareholder's Equity over Number of Common Shares.

\section{Earnings per Share}

Earnings per share considered as the most frequently used accounting information in value relevance studies. By using the formula given by them earnings per share calculated by taking earnings after tax, interest and depreciation divided by the total number of outstanding shares.

Moreover, Earning is a fundamental and prominent accounting variable when it comes to the investigation of the value relevance of accounting information. This is due to its superiority over cash flow in this regard. However, the market will look out for both cash flow and net book value if the earnings numbers are perceived to be inadequate (Abiodun, 2012). The earnings per share which is a parameter that can be used to measure the earnings ability of firms is required to be disclosed by companies quoted or about to be quoted in the public security market (Valix \& Peralta, 2009). The non-public enterprises to the extent that it would enhance their financial report comparability, are encouraged to present their EPS on the face of their income statements (Menaje, 2012). Contrary to the past practices of presenting information on the earnings per share in the form of primary and fully diluted EPS, the Financial Accounting Standard Board (FASB) now requires the disclose of both the basic and fully diluted EPS. This new practice of EPS disclosure is being motivated by the need to conform the calculation of EPS to the international standard and to assist the investors to better access the effect of potential dilution than that achieved under the primary EPS (Livant \& Segal, 2000). 
Most of the studies done on examine value relevance of earnings per share on share price, results reported to be significant and positive related with share price, this supported by the results found by Pathirawasam, (2010) in Sri-Lanka observed earnings per share to have positive value relevance on the market share price of 129 companies selected from 6 major sectors listed at Colombo stock exchange and other study done by different researchers including Tharmila,. (2013) and Vijitha, and Namalathan (2014) in SriLanka, by Ragab (2006) in Egyptian market, Adaramola and Oyerinde (2014) in Nigeria reported the same results. Earnings per share were sourced from profit and loss statement of the company by dividing the profit after tax by the number of outstanding shares for the respective period.

IFRS Adoption and the Value-Relevance of Accounting Information

Fair Value Accounting has shifted the paradigm of Accounting since "a major feature of IFRS qua standards is the extent to which they are imbued with fair value accounting" (Ball, 2005). In history, Fair value accounting "has played an important role in U.S. generally accepted accounting principles (GAAP) for more than 50 years" (Ryan, 2008).

It has been described as "the amount for which an asset could be exchanged, or a liability settled, between knowledgeable, willing parties in an arm's length transaction" (IFRS 3), apparently, it departs from historical cost accounting" (Jensen 2007). Although it shares similar features with liquidation valuation, it is considered as a concurrent exit value because it does not take cognizance of the accompanying cost of liquidating underlying assets as in the case of liquidation values. Accounting literature is replete with arguments against fair valuation. It has mostly been criticized on the ground that it brings about "adjustment that cause enormous fluctuations in earnings, assets and liabilities that are washed out over time and never realized" (Jensen 2007). However, testimonies of its radicalism in improving the scope for market discipline, accounting information and corrective actions are countless. "It is increasingly acknowledged in both the academic literature and the supervisory debate that the discipline exercised by informed and uninsured investors is an essential complement of supervisory control" (European Central Bank, 2004) created by the fair value accounting. It has also been practically proven that fair value accounting aligns positively both during upturns and downturns. Barth, GomezBiscarri\& Lopez-Epinosa (2012) observe:

"It leads to stronger cyclicality of accounting variable: in the upturns of the economy fair value would allow for revaluation of assets and in downturns only fair value accounting would recognize bad news when fair value is above the cost" (p.1).

\section{Perspective on Value Relevance}

There are different ways of interpreting value relevance, Francis and Schipper. (1999) identified four different approaches to studying the value relevance of accounting information as follows:

\section{The Fundamental Analysis view of Value Relevance}

The fundamental analysis approach to value relevance focuses on the usefulness of accounting information in equity valuation. Financial statement information is assumed to be relevant for valuation if portfolios based on this information are associated with abnormal returns. Thus, it is not assumed that the market is at all times efficient but that there is the possibility of earning abnormal returns simply by using accounting information.

\section{The Prediction view of Value Relevance}

This interpretation of value relevance is also related to fundamental analysis research. Accounting information is assumed to be value relevant if it can be used to predict future earnings, dividends, or future cash flows.

\section{The Information view of Value Relevance}

Accounting figures are assumed to have information content if the release of new information modifies investors' beliefs about future cash flows and thus causes price revisions. Information content studies use statistical association models to examine how the stock market reacts to the disclosure of new accounting information.

\section{The Measurement View of Value Relevance}

Under the measurement of value relevance, accounting information is value relevant if it captures or summarizes information that in turn affects stock prices.

\section{Theoretical Framework \\ Agency theory}

Institute of Chartered Accountant of Nigeria (ICAN), (2014) elucidated that Agency theory is based on the idea that when a company is first established, its owners are usually also its managers. As a company 
grows, the owners appoint managers to run the company. The owners expect the managers to run the company in the best interests of the owners; therefore a form of agency relationship exists between the owners and the managers. Agency theory addresses problems that arise due to differences between the goals or desires between the principal and agent. This situation may occur because the principal isn't aware of the actions of the agent or is prohibited by resources from acquiring the information. For example, company executives may have a desire to expand a business into other markets. This will sacrifice the short-term profitability of the company for prospective growth and higher earnings in the future. However, shareholders that desire high current capital growth may be unaware of these plans.

Kipchoge, (2015) adopted the theory on the premise that managers (agents) have better access to company's' accounting information can make credible and reliable communication to the market to optimize the value of the firm. Through financial reporting they communicate to the users of financial reports information that is useful in making choices among alternative uses of scarce resources. This study adopted the agency theory owing to the fact that financial information presentation signifies the stewardship role of an agent to his principal as in the case of information disclosure to uses following the former Nigeria Statement of accounting Standard during the pre IFRS adoption and the Post adoption period.

\section{Review of Empirical Studies}

Quite number of researches has been carried out locally and outside Nigerian borders on value relevance on accounting information within and outside the new accounting reporting for or against the established theories.

Beijer, Dekimpe, Dutordoir, and Verbeeten (2008) study the impact of inter-brand value announcements on the value relevance of brand by documenting a statistically and economically significant effect of brand value announcement on stock prices in Erasmus. That is, stock price are generally increasing in the magnitude of the brand value charged.

Omaima, Peter, Gianluigi and David (2008) studied the value of voluntary and mandatory disclosure in a market that applies International Accounting Standards (IAS) with limited penalties for noncompliance employed panel-data analysis, their results show that, after controlling for factors such as asset size and profitability, mandatory disclosure has a highly significant but negative relationship with firm value, although a puzzling result from a traditional perspective, it is consistent with the predictions of analytical accounting models, which emphasize the complex interplay of factors determining disclosure effects.

Pourheydari, Aflatooni and Nikbakat (2008) compare the combined value relevance of dividends and book value with the value relevance of earnings and book value and their relationship with market value of shares in Tehran Stock Exchange from 1996 to 2004. Their results show a positive relationship between dividends, book value and earnings with stock market value. They also find that dividends have information content. The information content of dividends, combination of book values and earnings and combination of book values and dividends are approximately equal. The value relevance of all variables however was found to decline over time.

Alali and Foote (2008) examined earnings-returns association in the Abu Dhabi Securities Market from 2000-2006. They found that there was an overall significant positive association between earnings level and returns in Abu Dhabi Securities Market. In their work, the positive significant relationship was more obvious in 2000, 2001, 2003 and 2006. Adela, Anuţa and Silvia (2010) findings confirm that the revaluated amounts of tangible assets are value relevant-and verify the predictive and feedback value, timeliness, reliability, and the possibilities for fair value implementation, characteristics which have been selected for testing. However, their own results are less consistent than the outcome of the variable which reflects the equity growth due to profit, which leads to a moderate value relevance of fair value in the case of revaluated tangible assets.

Vishnani and Shah (2008) determined the value relevance of financial reporting in India and describe value relevance as the ability of the financial information contained in the financial statements to explain the stock market measures. Their study explained the likely impact of financial reporting by listed companies on the market prices of their shares. The result of this study reveals that value relevance of published financial statements is insignificant. However, ratios based on these financial statements 
show significant association with stock market indicators. Further, through this study, they also explored the value relevance value additively of cash flow. They concluded that despite the widespread use and continuing advancement in accounting information and reporting practices, there is some concern about their not carrying enough value in the eyes of the shareholders or investors.

Habib and Elhamaney (2009) adopted the Pope and Wang's (2004) residual income specification instead of the commonly used Ohlson model to ascertain the value relevance of accounting information in Egyptian equity market. The study was drawn up from financial statements of 88 firms as of the year end 2005. Their result shows a positive correlation between cash flow and equity market values in Egypt. They further state that when the model estimation is based on earnings components of accounting accruals, the valuation weight of abnormal earnings goes up by about a factor of three in order to make up for the negative correlation between accounting accruals and equity market values. This supports the study major findings that accounting accruals are value relevant.

Oyerinde (2009) investigates the value relevance of accounting data in the Nigerian Stock Market, with the objective of establishing the relationship between accounting numbers and share prices in the Nigerian Stock Market. The study measures value relevance by the correlation coefficient between stock prices and some accounting numbers. The study shows that accounting information has the ability to capture information that affects equity values and that there is relationship between accounting numbers and share prices in Nigerian Stock Market. This study however shows a number of serious limitations: the time scope for this study was narrow, such that conclusions from this study could not be compared to studies done in more matured markets. It also did not take into cognizance the factor of scale as well as the effects of heteroscedasticity.

Karunarathne and Rajapakse (2010) studied the value relevance of earnings and cash flow in determining stock prices by paying attention to firm size effects on value relevance in Colombo stock exchange. The authors used both return model and price model to determine the value relevance of financial statement information and found that the value relevance of accounting information under the price model has more explanatory power than that of the return model, earnings per share was found to be more relevant in the study.

On another study, Belesis and Sorros (2010) established that both earnings and book values are value relevant and can explain the share price in the same degree in Greek listed firms. However, the major limitation of this study is that it made use of data from all business sectors except banking, finance, and insurance, which makes it impossible to pin the findings to a specific industry.

Abubakar (2010) conducted an empirical investigation using Ohlson model on the value relevance of accounting information of listed new economy firms in Nigeria. The study aimed at establishing the level at which accounting information of the firms such as book values and earnings per share influence the share price valuation. The study found that accounting information published by the firms in Nigeria has no significant value relevance to the users of the information. However, the firms considered in this study are new economy firms known as Telecommunication, Media and Technology (TMT) firms whose assets are largely intangible and are not included in the financial statements.

Perara and Thrikawala (2010) addressed the relevance of AI on investor's stock market decisions in Commercial Banks registered under Colombo Stock Exchange (CSE) in Sri Lanka used correlation coefficient on data of the AI in the published financial statements of Commercial banks registered under CSE, covering a period of 5 years from 2006 to 2009.Their finding reveals a relationship between Accounting Information and Market Price per Share, further revealed that investors still consider Accounting Information which contain in the published financial statements of Commercial Banks registered under CSE for the stock market decisions in Sri Lanka.

Dimitropoulos, Asteriou and Koumanakos (2010) investigate value relevance of earnings and cash flows within the Greek banking industry, considering other risk factors in the industry. They report that earnings have incremental information content that are beyond cash flow. In addition, there is positive impact but not significant association with returns earnings and other risk factors having negative impact from the valuation process with regards to bank size. 
Oka for and Ogiedu (2011) examine the potential effects of the adoption and implementation of IFRS in Nigeria from the perspective of stakeholders. It presents the results from a questionnaire survey of a sample of accounting lecturers, auditors and accountants. The data were analyzed using the Chi Square. The study found that International Financial Reporting Standards have the potential for yielding greater benefits than current GAAP, improve business performance management and impact on other business functions apart from financial reporting. The study also finds that IFRS adoption will add to financial reporting complexities and increase compliance with accounting standards.

Keener (2011) examines the differences in the value relevance of earnings and book values across industries. He presents evidence that joint value relevance of earnings and book values had not declined, even though the incremental value relevance of earnings increased; while the vale relevance of the book values was unchanged for the period. Using a sample of firms quoted in the Athens Stock Exchange over the period 1996-2008.

Glezakos, Mylonakis and Kafuoros (2012) examine the impact of earnings and book values on share prices in Athens; they find that the explanatory power of earnings and book values in share prices had increased over time. They also provide evidence that in the last years earnings played an increasingly declining role in the determination of share prices relative to book values.

Abiodun (2012) conducted a study on the value relevance of accounting information in corporate Nigeria using simple descriptive statistics coupled with the logarithmic regression models. The study covered the period between 1999 and 2009, and taking 40 companies from various sectors of the Nigerian economy as samples. The study revealed that earnings is more value relevant than book values and by extension that, the information contained in the income statements, which is proxy by the earnings, dictates the corporate values of firms in Nigeria more than the information contained in the balance sheet, proxy by the book values.

Rahman, (2012) examines the value relevance of earnings and book value of equity (individually and in aggregate), relative to price and return models, for Jordanian industrial companies for the period 1992 to
2002. The main findings of this paper are twofold. First, relative to price model, the value relevance of both earnings and book value (individually) have increased, whilst the value relevance of earnings increased and book value became irrelevant in their combination. Secondly, relative to return model, the value relevance of earnings either individually or in aggregate has increased while that of book value has declined. Overall, it is found that earnings are more important in explaining the variance in share price and return than book value. Furthermore, the results indicate that earnings and book value individually are more value relevant in price model. In contrast, these variables in aggregate are more value relevant in return model. The study shows that earnings help more in explaining market values in Jordanian industrial companies. This paper is the first in using price and return models in one study in Jordan.

Halonen, Parlovic and Pearson (2012) employ a simplified Ohlson's (1995) model; investigate value relevance of financial reporting in Sweden after the introduction of the International Financial Reporting Standard in 2005. They find that value relevance of book values had increased but the value relevance of earnings had decreased over the period.

Babalola (2012) This study primary investigates the value relevance of accounting information in corporate Nigeria and employs simple descriptive statistics coupled with the logarithmic regression models to examine this interaction between the period 1999 and 2009, and taking 40 companies from various sectors of the Nigerian economy as samples, the logarithmic regression models is more appropriate in investigating this relationship than any other model because it has some unique statistical properties over and above other models and tends to provides better results for analyses and evaluation. findings shows that earnings is more value relevant than book values by extension that, the information contained in the income statements, as ably proxy by the earnings, dictates more the corporate values of firms in Nigeria than the information contained in the balance sheet, as ably proxy by the book values.

Isenmila and Adeyemo (2013) adopt the questionnaire survey method to seek respondents' views on the subject matter. Understanding firms' adoption of IFRS can allow for insights into the benefits and costs colligated with such adoption in Nigeria. Specifically, the study employed the One Way Repeated Measure 
Analysis of Variance, and the Likelihood Ratio Test, otherwise referred to as G-test or maximum likelihood statistical significance test, in resolving the three hypotheses in the paper. The results show that there is a statistically significant difference in the perception of the stakeholders about the desirability of the mandatory adoption of IFRS.

Melissa (2013) addresses the relationship between share price and bottom line accounting information as dividends, earnings and book value in the Nairobi Stock Exchange. The study shows that earnings and book values are significantly associated with share values, though book value was found to be least significant of the three variables.

Ayzer and Cema (2013) examine the value relevance of financial statement information in Turkish Stock Markets during the period 1997-2011, using the Ohlson (1995) mode. Their result shows that combined book values and earnings are significantly value relevant in explaining stock prices in the Turkish Stock Markets. Book values and earnings were individually significantly value relevant, with book values having higher explanatory power than earnings.

Sibel (2013) investigates the value relevance of accounting information in pre and post financial periods of IFRS adoption for Turkish listed firms. Market value per share is related to book value per share and earnings per share by using the Ohlson model (1995). Overall book value is value relevant in determining market value or stock prices. The result shows that value relevance of accounting information has improved in the post IFRS period considering book values while no improvement has been observed in value relevance of earnings.

Tharmila and Nimalathasan (2013) examine the impact of value relevance of accounting information on market vulnerability of the listed manufacturing companies in Colombo stock exchange (CSE). Using one of accounting based measure of market vulnerability which is measured by market price per share. The sample of this study composed of twelve companies listed in the CSE and period of 5 five years from 2009 to 2013. The required data and information for the study were gathered from published annual reports, fact book, and website of listed companies in CSE from 2009 to 2013. Descriptive and inferential statistics were used for this purpose for the study. The results revealed that earning per share (EPS) and net assets value per share (NAVPS) significantly impact on market vulnerability. Further EPS and NAVPS are significantly correlated with market vulnerability.

Nyabundi (2013) examined the relationship between share prices and dividends, earnings and book values for companies listed on the Nairobi Securities Exchange (NSE) in Kenya for the six years period between 2005 and 2010. Using panel data analysis the study found evidence that there is a positive and significant relationship between stock prices and dividends, earnings and book values for the firms listed on the NSE. The study established that dividends have more explanatory power compared to earnings and book values.

Uthman and Abdul-Baki (2014) examined the effect of IFRS adoption on the performance evaluation of a case firm using some financial ratios selected from four major categories of financial ratios. The study was conducted through comparison of the ratios that were computed from IFRS based financial statements and Nigerian GAAP based financial statements. A One-Sample Kolmogorov-Smirnov Test was conducted to test for data normality. Mann-Whitney U test was employed in testing whether significant difference exists between the pair of ratios when the normality test showed a non-normal distribution of the data set. The result of the Mann- Whitney U test showed that there is no significant difference between the pair of ratios at $5 \%$ level of significance. It was concluded that the disclosure of IFRS compliant set of financial statements was not attributable to higher performance evaluation, through ratios, of the case firm. Rather, such disclosure could have been motivated by the capital needs theory or signaling theory.

In the study of Mechelli and Cimini (2014), they state that, net income is more value-relevant than comprehensive income (CI) in Europe, but total OCI for the period adds relevant information on net income for those items already disclosed in net income and book value. Additionally, Dhaliwal et al. (1999) found improvement on the association between returns and income as well as OCI. Furthermore, Lee and Park (2013), by adding control variables (audit size) report incremental value relevance of OCI, the result showing that there is incremental value relevance to the aggregate OCI. 
Vijltha and Nimalathasan (2014) study the value relevance of accounting information in the Colombo Stock Exchange. The study finds significant association of Earnings Per Share, Net Asset Value Per Share and Return On Equity, with share prices of listed firms on the Exchange.

Adaramola and Oyerinde (2014) examine the value relevance of accounting information of quoted companies in Nigeria using a trend analysis. Secondary data were sourced from the Nigerian Stock Exchange Fact Book; Annual Financial Reports of Sixty six (66) quoted companies consisting of financial and non-financial firms in Nigeria and the Nigerian Stock Market annual data. The Ordinary Least Square (OLS) regression method was employed in the analysis. The study reveals that accounting information on quoted companies in Nigeria is value relevant. However, the study reveals further that the value relevance of accounting information does not follow a particular trend within the period under study. While the value relevance was weak in the periods of political crisis caused by military dictatorship (1992-1998) and global economic crisis (2005-2009), it was high in the other periods.

Oshodin and Mgbame (2014) set out to conduct a comparative study on the value relevance of accounting information in the Nigeria banking and Petroleum sectors. 10 companies where randomly selected from each of these sectors. Data were collected on the Market Price per Share (dependent variable), Earning per Share, Book Value of Equity, and Leverage (independent variables) for the period 2007-2011, from the annual financial reports of the selected companies. The study hypothesized that there is no difference in the value relevance of accounting information in both the banking and oil and gas sectors and hence, the study compare the value relevance of accounting numbers in these sectors. Multiple regressions analysis was adopted for the analysis of the data and the Ordinary Least Square was the method of estimation. The regression results revealed among the following that: the EPS information is the most considered by investors when deciding the share price and that the financial information in the oil and gas is more value relevant compare to the financial information disclosed by companies in the banking sector.

In another study by Okoye, Okoye and Ezejio for (2014) assessment of the impact of International
Financial Reporting Standard on stock market movement and extent at which it can improve the position of corporate organization in Nigerian capital market. Using the stock price and shares traded during two years periods, it observed that the adoption of IFRS in Nigeria will enhance credible financial statements that will also provide a basis for the strength of a corporate entity in capital market hence is a welcome development in Nigerian economy.

Adaramola and Oyerinde (2014) examines the value relevance of accounting information in the Nigerian stock market with a view to determining whether accounting information has the ability to significantly affect share prices of quoted firms. This study used secondary data to investigate the value relevance of accounting data. The secondary data were sourced from the Nigerian Stock Exchange Fact Books, Annual Financial reports of companies quoted on the Nigerian Stock Exchange and the Nigerian Stock Market Annual reports. The Generalized Least Squared (GLS) regression method was employed on the panel model for the analysis. Findings show that there is a significant relationship between accounting information and share prices of companies listed on the Nigerian C Stock Exchange. Information on earnings, dividend, book value and cash flows can be used to predict share prices of quoted firms. According to their study, this implies that accounting information serves as a guide to investors' investment decisions in Nigeria.

Baltariu (2015) assess the scientific literature referring to the value relevance of reported accounting information over a twelve year period starting from 2002 in Cluj-Napoca. The approach of the paper is a theoretical (conceptual) one. In order to complete the purpose of the paper we selected as research method the longitudinal qualitative analysis. The qualitative analysis carried out presents a deductive character. The conclusions regarding the general characteristics of the research field pertaining to the value relevance of reported accounting information are drawn based on the main results and scientific contributions identified in the research field of interest.

Adebimpe and Ekwere (2015) examines whether the mandatory adoption of IFRS has improved the value relevance of financial information in the financial statements of commercial banks in Nigeria. Using financial statement figures of 2010 and 2011 (preadoption period) and 2012 and 2013 (post-adoption) 
descriptive statistics and least square regression were employed, their result indicates that the equity value and earnings of banks are relatively value relevant to share prices under IFRS than under the previous Nigerian SAS; earnings per share is incrementally value relevant during post-IFRS period while book value of equity per share is incrementally less value relevant during the post-IFRS period.

Omokhudu and Ibadin (2015) the purpose of this paper is to contribute to the empirical literature on value relevance by examining the extent to which accounting information is associated with firm value, from an emerging market context. The paper uses the basic Ohlson (1995) model and the modification of the model that includes cash flow from operation, and dividends, to ascertain the value relevance of accounting information in Nigeria. The paper accommodates the documented relative inefficiency of the market by using stock price at three months and six months after year end as dependent variable. The study employs a pooled and panel data in the regression of share price and returns on accounting numbers. The ordinary least square (OLS) estimation and dynamic model estimation, with the Random and Fixed effects variants were used in the regression. The study finds that earnings, cash flow and dividends were statistically significantly associated with firm value but book value was related but not statistically significant.

Yusuf and Nor Asma (2015) discusses about the adoption of International Financial Reporting Standards (IFRS) by the Nigerian financial institutions. Nigeria have been using domestic accounting standard (NGAAP) for banks and nonbanks financial institutions known as Statement of Accounting Standards (SAS 10 Part 1 and SAS 15 Part 2) issued in 1990 and 1997 respectively for financial reporting. These domestic standards were adopted from International Accounting Standards (IAS 30) but have not been updated like IAS 30 as reported by the Report on Observance of Standard Codes (ROSC) of Nigeria in 2004 and 2011. The change in accounting regulations is as a result of the weaknesses of NGAAP and low disclosure requirements. IFRS reporting has more disclosures than NGAAP especially for financial institutions. Under NGAAP financial instruments have not been classified as in IFRS.

Asian (2015) examines the impact of IFRS on market performance of food and beverages manufacturing firms in Nigeria. Earnings per Share, Price Earnings Ratio and Dividend Yield were selected as performance criterion. Data were collected and divided into pre and post IFRS- Comparative analysis and $\mathrm{T}$ test was done to ascertain influence of pre and post IFRS adoption on market performance of the firms. Findings indicate that differences on market performance between Pre and Post IFRS periods are not significant suggesting a weak correlation between adoption of IFRS and market performance of quoted food and beverage manufacturing firms in Nigeria Stock Exchange.

Latifat (2015) empirically examines whether the mandatory adoption of IFRS has improved the value relevance of financial information in the financial statements of quoted cement companies in Nigeria. The population constituted the five listed cement company listed on the Nigeria Stock Exchange(NSE) as at the year 2010 sample were selected based on the activeness of company. Data were extracted from financial statement figures of 2010 and 2011 (preadoption of IFRS) and 2012 and 2013 (post-adoption of IFRS). Descriptive statistics and regression were conducted to analyze the effect of IFRS adoption on the accounting information quality using Stata version 12.The study finds that the earning per share, book value of equity and share prices of Cement Company have significantly improved following IFRS adoption, although earnings per share proved more significant compared to book value of equity.

Abubakar (2015) assessed the joint incremental value relevance of intangibles assets, brands, not recognized in the current accounting practice. The study also explores the contribution of these assets towards improving the informative quality of accounting information to the users; and assesses the reliability of reporting intangible as assets. Using a sample of nine high-technology firms during the period of seven years (2005-2011), the study employed Ordinary Least Square Regression technique for data analysis using Edward, Bells and Ohlson Price model. The study found that, there is joint incremental value relevance of recognizing intangible assets in the statement of financial positions of High-Technology firms in Nigeria at $99 \%$ confidence level. That is, recognizing intangible assets, brand in this case in the statement of financial position of listed hightechnology firms in Nigeria will increase the quality of accounting information of the firms. Similarly, the 
study found that intangible assets are value relevance and reliable.

Mwila (2015) aimed in providing empirical evidence related to value relevance of earnings per share, book value per share, return on equity and assets turnover ratio on the share price of public sector banks listed in Bombay stock exchange (S\&P BSE 500). Study based on the uses of secondary data. Two panel data techniques (i.e. Fixed effect model and Random effect model) employed in examine the value relevance of accounting information in public sector banks stock. Earnings per share reported to have positive relationship and statistically significant with share price. While book value per share, return on equity and assets turnover ratio found to have negative relationship and statistically insignificant with share price. On the other hand earnings per share, book value per share and return on equity found to have positive correlation with share but the positive correlation between return on equity and share price reported to be very low.

Abata (2015) examined the impact of International Financial Reporting Standard (IFRS) on financial reporting practices of corporate establishments in Nigeria. Data were collected from 50 employees of KPMG (a leading professional financial services provider) through the use of structured questionnaire and analyzed using mean scores, standard deviation and Pearson Chi-square analysis. The findings revealed that IFRS provides better information for regulators than GAAP (mean $=4.72$ ). The finding further showed that IFRS directly affects how earnings and other key aspect of the business are accounted and reported for $($ mean $=4.68)$. However, the results of the study showed that changes in business processes and operations, financial position of companies and reduction in cost of finance were the least contributions of IFRS to financial reporting practices of KPMG. The results of Pearson Chi square analysis showed that financial reports prepared under IFRSs enhanced best practices in a corporate organization (Pearson Chi-Square $=37.857$ ); financial statements prepared in line with IFRS provides greater benefits than the former GAAP (SAS) (Pearson Chi-Square $=75.763$ ); the compliance with IFRS promotes cross border investment and access to (Pearson Chi-Square $=63.128$ ); and compliance with IFRS will relatively improve the performance of companies $($ Pearson Chi-Square $=20.417)$.
Lawani, Umanhonlen and Okolie (2015) centered on conservatism and value relevance of accounting information to quoted firms in Nigeria stock exchange. In order to ascertain the impact of conservatism on value relevance of accounting information, secondary source of data collection, statistical instruments such as multiple regression and correlation coefficient were used in the analysis of data collected. It was discovered among others that there is the existence of a significant inverse relationship between Market-based conservatism (BMCONA) and Earnings per share (EPS) for the pooled OLS, fixed and random effects model. The results suggest that higher conservative practices by companies will affect the in formativeness of financial estimates and declines in stock returns may be seen as an outcome of the markets assessment of disclosure credibility.

Charumathi and Suraj (2015) examine value relevance of earnings and book value on the share price of 14 banks ( 6 banks from private banks sector and 8 banks from public banks sector) listed in Bombay stock exchange from 2001 to 2010.They employed regression analysis with theoretical framework of Ohlson valuation model (1995) and reported accounting information of book value and earnings per share to have positive and significant relationship with share price of 14 banks stock. The result found that book value per share found to be more relevant than earnings for equity valuation of banks stock.

Kaaya (2015) measured as the statistical association between financial statement figures and stock market values. This explanatory study uses desktop and library methodology to explore and present the worldwide extant empirical research evidence on the IFRS value relevance. The paper reveals that existing empirical studies have concentrated in developed capital markets with growing interest in developing countries context and report mixed and incoherent results which are difficult to generalize. It further divulges that IFRS can be equally useful in developed and frontier capital markets when coupled with appropriate enforcement mechanisms. The results from the review imply that IFRS is a critical determinant for quality reporting but not a conclusive determinant.

Elbakry, Nwachukwu, Abdou and Elshandidy (2016) investigate the changes in the value relevance of 
accounting information before and after the mandatory adoption of IFRS in Germany and the UK. Regression analysis was used for data analysis. The study shows that the incremental value relevance of both earnings and book values are considerably higher in the long term for firms in the UK than in Germany. Secondly, a simultaneous addition of accounting and macroeconomic variables in an extended model, which indicates a significant rise in the relative predictive power of the book value of equity.

Jinadu (2016) Examines whether the adoption of International Financial Reporting Standards (IFRS) has improved the quality of accounting information in the area of value relevance as it affects the Nigerian quoted firms. Regression method was used to analyses the data collected. The findings revealed that the adoption of IFRS has a positive and significant effect on the value relevance of accounting information. The study recommends that the government should empower the relevant bodies to incorporate more measures to improve the quality of the financial reporting in order to increase the value relevance of financial statements.

Uwalomwa, Agba, Jimoh, Olubukunola and Jimoh (2017) examined in the impact of IFRS adoption on earnings predictability of listed banks in Nigeria. A sample of 11 listed banks in Nigeria. Categorically, data were obtained from the financial statement 2013 to 2014 (post-adoption period) and 2010 to 2011 (preadoption period). The data obtained were analyzed using regression on the Statistical Package for Social Sciences (SPSS). The study found a decrease in the ability of current earnings to predict future earnings after the adoption period. Thus, IFRS adoption has a negative impact on earnings predictability.

\section{Summary of Empirical Literature}

Prior literature provides evidence on the value relevance of accounting information as measured in balance sheet, income and expenditure, comprehensive income and cash flows statements. Balance sheet disclosures on assets and liabilities provide information needed by the investors for decision-making in financial institutions. Gaston, et al (2003); Wulandri and Rahman (2004); find that accounting institutional environment has a stronger positive association with value relevance of accounting earnings than legal environment. Ragab and Omiran (2006); Ben, and Nachi's (2007); Beijer, et al (2008); Pourheydari, et al (2008) show a positive relationship between dividends, book value and earnings with stock market value. Habib and Elhamaney(2009); Oyerinde (2009). Pereia and Thrikawala (2010); Perara and Thrikawala (2010) reveals a relationship between Accounting Information and Market Price per Share. Halonen, et al (2012); Melissa (2013); Ayzer and Cema (2013); Tharmila and Nimalathasan (2013); Nyabundi (2013); Mechelli and Cimini (2014); Adaramola and Oyerinde (2014); Okoye et al (2014); Yusuf and Nor Asma (2015); Baltariu (2015); Adebimpe and Ekwere (2015); Omokhudu and Ibadin (2015); Latifat (2015) and Abubakar (2015) show that accounting information has the ability to capture information that affects equity values and that there is relationship between accounting numbers and share prices in Nigerian Stock Market.

In opposite reaction, Carazavan-Jeny, and Jean-Jeny, (2003); Ragab and Omiran (2006) found that stock prices in Egypt are less information about the future value of the firm than accounting information. Ortega (2006); Ayed and Abaoub (2006); Aleksanyan (2007); Omaima, et al (2008); after controlling for factors such as asset size and profitability, mandatory disclosure has a highly significant but negative relationship with firm value. Jones and Smith (2011); Olga and Veltri (2012); Babalola (2012) findings shows that earnings is more value relevant than book values by extension that, the information contained in the income statements, as ably proxy by the earnings, dictates more the corporate values of firms in Nigeria than the information contained in the balance sheet, as ably proxy by the book values (Vijltha \& Nimalathasan, 2014).

Few of these prior studies were conducted on value relevance of accounting information before the implementation of IFRS in Nigeria while others were conducted in foreign countries, such studies like; Sibel (2013) was carried out in pre and post IFRS on Turkish listed firms. Latifat (2015) studied value relevance on five cement companies in Nigeria between 2010 to 2013, and found that earnings per share, book value of equity and share price have improve following IFRS adoption. Adebimpe and Ekwere (2015) study on pre IFRS and Post IFRS in Nigerian banks and revealed that earnings and equity value are value relevant to share price under IFRS while book value is less value relevant. There is a limited study on Nigerian manufacturing companies in relation to International financial reporting 
standard, besides most of the studies on value relevance of accounting information on IFRS financial periods were in developed countries. In addition their results were inconsistent and this might be as a result of the methodology used. In view of this, this study however set out to fill the gap by adding additional statistical tool to determine whether value relevance of accounting information in Nigerian manufacturing firms has improved after the implementation of IFRS.

\section{METHODOLOGY}

\section{Research Design}

Ex-post facto research design was adopted for the study. This is appropriate because the study aims at measuring the relationship between one variable and another, in which the variables involved are not manipulated by the researcher.

The population of the study consists of sixty four (64) manufacturing companies quoted on the Nigerian Stock Exchange. The companies are grouped into 5 categories by the Nigerian Stock Exchange. The groupings are (1) Consumer goods, (2) Healthcare, (3) Industrial goods, (4) Natural resources and (5) Conglomerate.

\section{Sample Size and Sampling Techniques}

A sample size of 54 manufacturing companies was selected from the population of 64 using Taro Yamene technique. The procedure is shown below:

$$
\mathrm{n}=\frac{\mathrm{N}}{1+\mathrm{N}(\mathrm{e})^{2}}
$$

Where:

$\mathrm{n}=$ overall sample size

$\mathrm{N}=$ Total population size

$\mathrm{I}=$ Constant

$\mathrm{E}=$ Margin of error, $(5 \%)$ was chosen as the margin of

error

Calculation of the sample size is as follow;

$$
\begin{aligned}
& \mathrm{n}=\frac{\mathrm{N}}{1+\mathrm{N}(\mathrm{e})^{2}} \\
& \mathrm{n}=\frac{64}{1+64(0.05)^{2}} \\
& \mathrm{n}=\frac{64}{1.17} \\
& \mathrm{n}=54
\end{aligned}
$$

Stratified random sampling was employed in selecting the manufacturing companies to be included in the sample. In stratified random sampling, the entire population is organized into homogenous subjects and a random sample is drawn from each subset or strata (Ezinwa, 2011). Each of the 5 grouping is regarded as strata. The sample size was apportioned among the 5 stratum and random sampling technique was applied in selecting the companies in each stratum.

\section{Method of Data Analysis}

To determine whether IFRS has impacted on value relevance, the study divided the periods into pre-IFRS (2008-2011) and post-IFRS (2012-2015).

Regression analysis was employed to determine if there is a significant difference between the pre-IFRS and post IFRS on value relevance of accounting information. The depended variable is market price while the independents variables are book value per share (BVPS), earnings per share (EPS) and cash flow.

\section{Model Specification}

The researcher adopted Ohlson (1995) price model from two financial reports indicators (financial position and comprehensive income) is being used to test the value relevance of financial reporting. This was used to explore the relationship between market value with two main financial reporting variables; the book value per share which represents financial position and earnings per share which represents comprehensive income.

By the Ohlson (1995) Model:

MKTPjt $=\beta 0+\beta 1$ BVSHjt $+\beta 2$ EPSjt + ejt

Where:

MKTPjt $=$ the market price per share (SP) of firm $j$ at time $t$

BVSHjt $=$ Book value per share of firm $j$ at time $t$

EPSjt = Earnings before extraordinary items per share of firm $j$ at time $t$

$\beta 0=$ Constant or intercept

$\beta 1-3=$ Coefficients of explanatory variables

Ejt $=$ Error term.

The researcher modified Ohlson (1995) Model by adding a third variable (cash flow) because it is data or variable that can guide the investors in their pricing of shares (Vishnani and Shah, 2008). 
The modified Ohlson (1995) Model:

MKTPjt $=\beta 0+\beta 1$ BVSHjt $+\beta 2$ EPSjt $+\beta 3$ CSHFLWjt + ejt

Where:

MKTPjt = the market price per share (SP) of firm $\mathrm{j}$ at time $\mathrm{t}$

BVSHjt $=$ Book value per share of firm $\mathrm{j}$ at time $\mathrm{t}$

EPSjt = Earnings before extraordinary items per share of firm $\mathrm{j}$ at time $\mathrm{t}$

CSHFLW $\mathrm{j} \mathrm{t}=$ Cash flow of firm $\mathrm{j}$ at time $\mathrm{t}$

$\beta 0=$ Constant or intercept.

$\beta 1-3=$ Coefficients of explanatory variables

\&jt $\quad=$ Error term.

Chow test structural stability version of the ordinary least square method of econometric regression is used to test the formulated hypotheses. Chow test is a special kind of F-test propounded by Chow and it based on the idea that a series of data can contain a structural break. In this case we are interested in finding out whether the series of data in our variables had a structural break following the adoption of IFRS in 2012.

The method uses a F-test to determine whether the perceived structural change has a measurable effect on the study periods and aim is to determine whether a single regression covering the periods before and after the adoption of IFRS in 2012 is more efficient than two separate regression involving splitting of data into two samples, one representing the period before 2012 and the other for the period after 2012 .

\section{Chow Specification}

a) A single or pooled regression to fit the whole series of data (before and after IFRS adoption)

$\mathrm{Y}_{1}=\mathrm{a}_{\mathrm{i}}+\mathrm{b}_{\mathrm{i}} \mathrm{X}_{1}+\mathrm{u}_{\mathrm{i}}$

Where $\mathrm{Y}_{1}=$ Market price (MKTP)

$\mathrm{X}_{1}=$ book value per share (BVPS), earnings per share (EPS) and cash flow (CSHFLW)

b) Regression for the period before 2012 adoption of IFRS

$\mathrm{Y}_{2}=\mathrm{a}_{\mathrm{i}}+\mathrm{b}_{\mathrm{i}} \mathrm{X}_{2}+\mathrm{u}_{\mathrm{i}}$

Where $\mathrm{Y}_{2}=$ market price $(\mathrm{MKTP})$

$\mathrm{X}_{2}=$ book value per share (BVPS) earnings per share (EPS) and cash flow (CSHFLW)

c) Regression for the periods after the 2012 adoption of IFRS;

$\mathrm{Y}_{3}=\mathrm{a}_{\mathrm{i}}+\mathrm{b}_{\mathrm{i}} \mathrm{X}_{3}+\mathrm{u}_{\mathrm{i}}$

Where $\mathrm{Y}_{3}=$ market price (MKTP)

$\mathrm{X}_{3}=$ book value per share (BVPS) earnings per share (EPS) and cash flow (CSHFLW
Chow test statistics is obtained as follows;

$$
\mathrm{F}=\frac{\mathrm{RSS}_{1}-\left(\mathrm{RSS}_{2}+\mathrm{RSS}_{3}\right) / \mathrm{k}}{\mathrm{RSS}_{2}+\mathrm{RSS}_{3} / \mathrm{n}-2 \mathrm{k}}
$$

Where:

RSS = Sum of Square residual

$\mathrm{k} \quad=$ Total number of variable included

$\mathrm{n} \quad=$ Total sample size

\section{Decision Rule:}

If the Chow test statistics is greater than the tabulated F-value, then the null hypothesis that is no structural break of change (that is there is no significant change) is rejected and vice versa

\section{DATA PRESENTATION}

\section{INTERPRETATION}

\section{Test of Hypotheses}

\section{Hypothesis One}

$\mathrm{H}_{\mathrm{O}}$ : The adoption of IFRS has not significantly improved the book value per share in determining market price of manufacturing companies in Nigeria.

\section{Table 1: Separate regression (before IFRS} adoption for BVPS)

Dependent Variable: MKTV

Method: Ordinary Least Square (OLS)

Sample: 4YEAR

Included Observation: 54

\begin{tabular}{|c|c|c|c|c|}
\hline $\begin{array}{c}\text { Variabl } \\
\text { e }\end{array}$ & Coefficient & Std. Error & $\begin{array}{c}\text { t- } \\
\text { Statist } \\
\text { ic }\end{array}$ & Prob \\
\hline MKTV & -13624.590 & 13813.632 & -0.986 & 0.01 \\
\hline BVPS & 32.571 & 40.067 & 0.813 & 0.49 \\
\hline $\mathbf{R}^{2}$ & .248 & $\begin{array}{c}\text { Mean } \\
\text { dependent } \\
\text { Var }\end{array}$ & & 245.6 \\
\hline $\begin{array}{c}\text { Adjust } \\
\text { ed R }\end{array}$ & -.127 & $\begin{array}{c}\text { S.D } \\
\text { Dependent } \\
\text { Var }\end{array}$ & & $\begin{array}{c}25.63 \\
7\end{array}$ \\
\hline $\boldsymbol{R S S}_{\boldsymbol{1}}$ & $\begin{array}{c}\mathbf{6 6 2 1 2 0 6 3 .} \\
\mathbf{0 5 2}\end{array}$ & $\begin{array}{c}\text { Durbin- } \\
\text { Watson } \\
\text { Statistics }\end{array}$ & & 1.991 \\
\hline $\boldsymbol{F}$ & 0.661 & & & \\
\hline $\boldsymbol{d} . \boldsymbol{f}$ & 2 & & & \\
\hline $\mathbf{N}$ & 54 & & & \\
\hline
\end{tabular}

Source: Regression Data Analysis (2017)

Table 2: Separate regression (After IFRS adoption for BVPS)

Dependent Variable: MKTV

Method: Ordinary Least Square (OLS) 
International Journal of Trend in Scientific Research and Development (IJTSRD) ISSN: 2456-6470

Sample: 4YEARS

Included Observation: 54

\begin{tabular}{|c|c|c|c|c|}
\hline Variable & $\begin{array}{c}\text { Coefficien } \\
\mathrm{t}\end{array}$ & Std. Error & $\begin{array}{c}\text { T- } \\
\text { Statisti } \\
\mathrm{c}\end{array}$ & Prob \\
\hline Mktv & 85.381 & 14.630 & 5.836 & 0.302 \\
\hline Bvps & .049 & .017 & 2.980 & 0.221 \\
\hline $\mathbf{R}^{\mathbf{2}}$ & 0.816 & $\begin{array}{c}\text { Mean } \\
\text { Dependen } \\
\text { t Var }\end{array}$ & & 273.6 \\
\hline $\begin{array}{c}\text { Adjuste } \\
\mathbf{d ~ R} \mathbf{R}^{2}\end{array}$ & 0.724 & $\begin{array}{c}\text { S.D } \\
\text { Dependen } \\
\text { t Var }\end{array}$ & & $\begin{array}{c}45.09 \\
2\end{array}$ \\
\hline $\boldsymbol{R s s} \mathbf{2}$ & $\mathbf{1 6 4 . 0 4 8}$ & $\begin{array}{c}\text { Durbin- } \\
\text { Watson } \\
\text { Statistics }\end{array}$ & & 2.63 \\
\hline $\boldsymbol{F}$ & 8.879 & & & \\
\hline $\boldsymbol{d} . \boldsymbol{f}$ & 2 & & & \\
\hline $\mathbf{N}$ & 54 & & & \\
\hline Source & & & \\
\hline
\end{tabular}

Source: Regression Data Analysis (2017)

Table 3: Pooled regression (before and after IFRS adoption for BVPS)

Dependent Variable: MKTV

Method: Ordinary Least Square (OLS)

Sample: 8YEAR

Included Observation: 54

\begin{tabular}{|c|c|c|c|c|}
\hline $\begin{array}{l}\text { Variabl } \\
\text { e }\end{array}$ & Coefficient & $\begin{array}{l}\text { Std. } \\
\text { Error }\end{array}$ & $\begin{array}{c}\text { T- } \\
\text { Statisti } \\
\text { c }\end{array}$ & Prob \\
\hline MKTV & -3735.929 & 2842.859 & -1.314 & 0.000 \\
\hline BVPS & 4.217 & 4.247 & 0.993 & 0.815 \\
\hline $\mathbf{R}^{2}$ & 0.141 & $\begin{array}{l}\text { Mean } \\
\text { depende } \\
\text { nt Var }\end{array}$ & & 259.6 \\
\hline $\begin{array}{c}\text { Adjuste } \\
\text { d R }^{2}\end{array}$ & -0.002 & $\begin{array}{c}\text { S.D } \\
\text { Depende } \\
\text { nt Var }\end{array}$ & & $\begin{array}{c}37.59 \\
8\end{array}$ \\
\hline$R S S_{3}$ & $\begin{array}{c}88823204.2 \\
49\end{array}$ & $\begin{array}{l}\text { Durbin- } \\
\text { Watson } \\
\text { Statistics }\end{array}$ & & 0.668 \\
\hline$F$ & 0.986 & & & \\
\hline d. $f$ & 6 & & & \\
\hline $\mathbf{N}$ & 54 & & & \\
\hline
\end{tabular}

Source: Regression Data Analysis (2017)

To compute the Chow Test using the formula thus;

$$
\mathrm{F}_{\mathrm{cal}}=\frac{\mathrm{RSS}_{1}-\left(\mathrm{RSS}_{2}+\mathrm{RSS}_{3}\right) / \mathrm{k}}{\mathrm{RSS}_{2}+\mathrm{RSS}_{3} / \mathrm{n}-2 \mathrm{k}}
$$

( )- t-value, RSS - Residual Sum of Squares, ** $(p<0.05)-$ significant at $\alpha=0.05$
The tables above shows that;

Sum of Square residual for periods before and after IFRS adoption $=88823204.249$

Sum of Square residual for periods before IFRS adoption $=66212063.052$

Sum of Square residual for periods after IFRS adoption $=164.048$

Following the $F$ distribution with $(\mathrm{n}-2 \mathrm{k}) \mathrm{df}$ in the numerator and the denominator respectively, in this study, $k=2$, since there are only two parameters in each sub-regression and $\mathrm{n}=\mathrm{n}-2 \mathrm{k}=54-4=54$

Therefore,

$\mathrm{F}_{\mathrm{cal}}=\frac{\mathrm{RSS}_{1}-\left(\mathrm{RSS}_{2}+\mathrm{RSS}_{3}\right) / \mathrm{k}}{\mathrm{RSS}}$

$$
\begin{aligned}
& =\frac{(88823204.249-(66212063.052+164.048) / 2}{66212063.052+164.048 / 54-2 \times 2} \\
& =\frac{88823204.249-66212227.100 / 2}{66212227.100 / 50}
\end{aligned}
$$$$
=\underline{11305488.6}
$$$$
1324244.54
$$$$
=8.5373
$$

$$
\mathrm{F}_{\mathrm{tab}}=\mathrm{F}_{\alpha,}\left[\mathrm{k},\left(\mathrm{n}-\mathrm{2}_{\mathrm{k}}\right)=\mathrm{F} 0.05,[2,6]=5.143\right.
$$

From the results Chow Test computed above, at $\alpha=0.05, F_{\text {cal }}=8.5373>F_{\text {tab }}=5.143$ at $(2,6)$ degree of freedom. We therefore accept the alternative hypothesis $\left(\mathrm{H}_{1}\right)$ and conclude that there is no structural change on organizational BVPS after adoption of IFRS method on 0.05level of significance. This implies that since adoption of IFRS in the firms at 0.05 level of significance there is a structural change in the BVPS. We therefore conclude that the adoption of IFRS has significantly improved the book value per share in determining market price of manufacturing companies in Nigeria.

\section{Hypothesis Two}

Ho: The adoption of IFRS has not significantly improved the Earnings Per Share in determining market price of manufacturing companies in Nigeria.

\section{Table4: Separate regression (before IFRS adoption for EPS)}

Dependent Variable: MKTV

Method: Ordinary Least Square (OLS)

Sample: 4YEAR 
International Journal of Trend in Scientific Research and Development (IJTSRD) ISSN: 2456-6470

Included Observation: 54

\begin{tabular}{|c|c|c|c|c|}
\hline $\begin{array}{c}\text { Variabl } \\
\mathrm{e}\end{array}$ & Coefficient & $\begin{array}{l}\text { Std. } \\
\text { Error }\end{array}$ & $\begin{array}{c}\text { T- } \\
\text { Statist } \\
\text { ic }\end{array}$ & Prob \\
\hline $\begin{array}{c}\text { MKT } \\
\text { V }\end{array}$ & -3324.033 & $\begin{array}{c}2937.54 \\
8 \\
\end{array}$ & $\begin{array}{c}- \\
1.132 \\
\end{array}$ & 0.10 \\
\hline EPS & -6.828 & 7.884 & $\begin{array}{c}- \\
0.866 \\
\end{array}$ & 0.279 \\
\hline $\mathbf{R}^{2}$ & 0.273 & $\begin{array}{c}\text { Mean } \\
\text { depende } \\
\text { nt Var }\end{array}$ & & $\begin{array}{l}246060 . \\
588\end{array}$ \\
\hline $\begin{array}{c}\text { Adjust } \\
\text { ed } \mathbf{R}^{2}\end{array}$ & -0.091 & $\begin{array}{c}\text { S.D } \\
\text { Depend } \\
\text { ent Var }\end{array}$ & & $\begin{array}{c}25793.9 \\
76\end{array}$ \\
\hline$R S S_{1}$ & $\begin{array}{c}64064878 . \\
204\end{array}$ & $\begin{array}{l}\text { Durbin- } \\
\text { Watson } \\
\text { Statistic }\end{array}$ & & 9 \\
\hline$F$ & 0.750 & 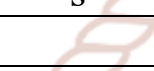 & 1 & 20 \\
\hline$d . f$ & 2 & & & \\
\hline $\mathbf{N}$ & 54 & 68 & $x^{\circ}$ & $1 \quad 1=$ \\
\hline
\end{tabular}

Source: Regression Data Analysis (2017)

Table 5: Separate regression (After IFRS adoption for EPS)

Dependent Variable: MKTV

Method: Ordinary Least Square (OLS)

Sample: 4YEARS

Included Observation: 54

\begin{tabular}{|c|c|c|c|c|}
\hline Variable & $\begin{array}{c}\text { Coefficien } \\
\mathrm{t}\end{array}$ & Std. Error & $\begin{array}{c}\text { T- } \\
\text { Statisti } \\
\mathrm{c}\end{array}$ & Prob \\
\hline MKTV & 127.583 & 10.784 & 11.831 & 0.688 \\
\hline $\mathbf{E P S}$ & .007 & .029 & 0.259 & 0.101 \\
\hline $\mathbf{R}^{\mathbf{2}}$ & 0.032 & $\begin{array}{c}\text { Mean } \\
\text { dependen } \\
\text { t Var }\end{array}$ & & 273.6 \\
\hline $\begin{array}{c}\text { Adjuste } \\
\mathbf{d} \mathbf{R}^{\mathbf{2}}\end{array}$ & -0.451 & $\begin{array}{c}\text { S.D } \\
\text { Dependen } \\
\text { t Var }\end{array}$ & & $\begin{array}{c}45.09 \\
2\end{array}$ \\
\hline $\boldsymbol{R S S} \boldsymbol{S}_{\mathbf{2}}$ & $\mathbf{8 6 3 . 3 9 1}$ & $\begin{array}{c}\text { Durbin- } \\
\text { Watson } \\
\text { Statistics }\end{array}$ & & 1.141 \\
\hline $\boldsymbol{F}$ & 0.67 & & & \\
\hline $\boldsymbol{d} . \boldsymbol{f}$ & 2 & & & \\
\hline $\mathbf{N}$ & 54 & & & \\
\hline $\mathbf{S}$ & & & & \\
\hline
\end{tabular}

Source: Regression Data Analysis (2017)

Table 6: Pooled regression (before and after IFRS adoption for EPS)

Dependent Variable: MKTV
Method: Ordinary Least Square (OLS)

Sample: 8YEAR

Included Observation: 54

\begin{tabular}{|c|c|c|c|c|}
\hline $\begin{array}{c}\text { Variabl } \\
\text { e }\end{array}$ & Coefficient & $\begin{array}{l}\text { Std. } \\
\text { Error }\end{array}$ & $\begin{array}{c}\mathrm{T}- \\
\text { Statisti } \\
\mathrm{c}\end{array}$ & Prob \\
\hline MKTV & -614.372 & 1486.609 & -0.413 & $\begin{array}{c}0.00 \\
4\end{array}$ \\
\hline EPS & 4.895 & 4.715 & 1.038 & $\begin{array}{c}0.87 \\
4\end{array}$ \\
\hline $\mathbf{R}^{2}$ & 0.152 & $\begin{array}{c}\text { Mean } \\
\text { depende } \\
\text { nt Var }\end{array}$ & & $\begin{array}{c}259 . \\
6\end{array}$ \\
\hline $\begin{array}{c}\text { Adjuste } \\
\text { d R R }^{2}\end{array}$ & 0.011 & $\begin{array}{c}\text { S.D } \\
\text { Depende } \\
\text { nt Var }\end{array}$ & & $\begin{array}{c}37.6 \\
0\end{array}$ \\
\hline $\mathrm{RSS}_{3}$ & $\begin{array}{c}87669276.1 \\
07\end{array}$ & $\begin{array}{l}\text { Durbin- } \\
\text { Watson } \\
\text { Statistics }\end{array}$ & & $\begin{array}{c}0.72 \\
3\end{array}$ \\
\hline $\boldsymbol{F}$ & 1.078 & $\mathrm{~h}$ & & \\
\hline d. $f$ & 6 & 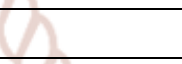 & & \\
\hline $\mathbf{N}$ & 54 & Y & & \\
\hline
\end{tabular}

Source: Regression Data Analysis (2017)

To compute the Chow Test using the formula thus;

$$
\mathrm{F}_{\mathrm{cal}}=\frac{\mathrm{RSS}_{1}-\left(\mathrm{RSS}_{2}+\mathrm{RSS}_{3}\right) / \mathrm{k}}{\mathrm{RSS}_{2}+\mathrm{RSS}_{3} / \mathrm{n}-2 \mathrm{k}}
$$

( )- t-value, RSS - Residual Sum of Squares, ** $(p<0.05)$ - significant at $\alpha=0.05$

The tables above shows that;

Sum of Square residual for periods before and after IFRS adoption $=87669276.107$

Sum of Square residual for periods before IFRS adoption $=64064878.204$

Sum of Square residual for periods after IFRS adoption $=863.391$

Following the $F$ distribution with $(\mathrm{n}-2 \mathrm{k}) \mathrm{df}$ in the numerator and the denominator respectively, in this study, $k=2$, since there are only two parameters in each sub-regression and $n=54-4=50$

Therefore,

$$
\begin{aligned}
\mathrm{F}_{\mathrm{cal}} & =\frac{\mathrm{RSS}_{1}-\left(\mathrm{RSS}_{2}+\mathrm{RSS}_{3}\right) / \mathrm{k}}{\mathrm{RSS}_{2}+\mathrm{RSS}_{3} / \mathrm{n}-2 \mathrm{k}} \\
& =\frac{87669276.107-(64064878.204+863.391) / 2}{64064878.204+863.391 / 54-2 \times 2}
\end{aligned}
$$$$
=\frac{87669276.1071^{-}-64065741.6 / 2}{64065741.6 / 50}
$$ 
International Journal of Trend in Scientific Research and Development (IJTSRD) ISSN: 2456-6470

$=\frac{11801767.2}{1281314.83}$

$=9.2107$

$\mathrm{F}_{\mathrm{tab}}=\mathrm{F}_{\alpha,}[\mathrm{k},(\mathrm{n}-2 \mathrm{k})=\mathrm{F} 0.05,[2,6]=5.143$

From the results, Chow Test computed above, at $\alpha=0.05, F_{\text {cal }}=9.2107>F_{\text {tab }}=5.143$ at $(2,6)$ degree of freedom. We therefore accept the alternative hypothesis $\left(\mathrm{H}_{1}\right)$ and conclude that there is a structural change on EPS after adoption of IFRS on 0.05level of significance. This implies that since adoption of IFRS in the firms at 0.05 level of significance there is a change in the EPS.

\section{Hypothesis Three}

Ho: The adoption of IFRS has not significantly improved the cash flow in determining market price of manufacturing companies in Nigeria.

Table 7: Separate regression (before IFRS adoption for CSHFLW)

Dependent Variable: MKTV

Method: Ordinary Least Square (OLS)

Sample: 4YEAR

Included Observation: 54

\begin{tabular}{|c|c|c|c|c|}
\hline Variable & Coefficient & $\begin{array}{l}\text { Std. } \\
\text { Error }\end{array}$ & $\begin{array}{c}\text { T- } \\
\text { Statist } \\
\text { ic }\end{array}$ & Prob \\
\hline MKTV & -6384.519 & $\begin{array}{c}2846.06 \\
0\end{array}$ & $2 . \overline{243}$ & 0.00 \\
\hline $\begin{array}{c}\text { CSHFL } \\
\mathrm{W} \\
\end{array}$ & $\begin{array}{c}\text { 4.604E- } \\
005\end{array}$ & 0.000 & 58 & 0.18 \\
\hline $\mathbf{R}^{2}$ & 0.633 & $\begin{array}{c}\text { Mean } \\
\text { depende } \\
\text { nt Var }\end{array}$ & & 6 \\
\hline $\begin{array}{c}\text { Adjuste } \\
\text { d R }^{2}\end{array}$ & 0.450 & $\begin{array}{c}\text { S.D } \\
\text { Depend } \\
\text { ent Var }\end{array}$ & & $\begin{array}{c}25.6 \\
38\end{array}$ \\
\hline$R S S_{1}$ & $\begin{array}{c}32321435 \\
967\end{array}$ & $\begin{array}{c}\text { Durbin- } \\
\text { Watson } \\
\text { Statistic } \\
\text { s } \\
\end{array}$ & & $\begin{array}{c}3.09 \\
4\end{array}$ \\
\hline$F$ & 3.451 & & & \\
\hline d. $f$ & 2 & & & \\
\hline $\mathbf{N}$ & 54 & & & \\
\hline
\end{tabular}

Source: Regression Data Analysis (2017)

Table 8: Separate regression (After IFRS adoption for CSHFLW)

Dependent Variable: MKTV
Method: Ordinary Least Square (OLS)

Sample: 4YEARS

Included Observation: 54

\begin{tabular}{|c|c|c|c|c|}
\hline Variable & $\begin{array}{c}\text { Coefficie } \\
\text { nt }\end{array}$ & $\begin{array}{l}\text { Std. } \\
\text { Error }\end{array}$ & $\begin{array}{c}\mathrm{T}- \\
\text { Statisti } \\
\mathrm{c}\end{array}$ & Prob \\
\hline MKTV & 144.705 & 22.887 & 6.323 & 0.01 \\
\hline $\begin{array}{c}\text { CSHFL } \\
\text { W }\end{array}$ & $\begin{array}{c}-8.089 \mathrm{E}- \\
008\end{array}$ & .000 & -0.850 & 0.49 \\
\hline $\mathbf{R}^{2}$ & 0.265 & $\begin{array}{c}\text { Mean } \\
\text { dependen } \\
\mathrm{t} \quad \mathrm{Var}\end{array}$ & & 273.6 \\
\hline $\begin{array}{c}\text { Adjusted } \\
\mathbf{R}^{2}\end{array}$ & -0.102 & $\begin{array}{c}\text { S.D } \\
\text { Depende } \\
\text { nt Var }\end{array}$ & & $\begin{array}{c}45.09 \\
2\end{array}$ \\
\hline$n \mathrm{RSS}_{2}$ & 655.460 & $\begin{array}{c}\text { Durbin- } \\
\text { Watson } \\
\text { Statistics }\end{array}$ & & 1.016 \\
\hline $\boldsymbol{F}$ & 0.723 & & & \\
\hline$d . f$ & $\frac{2}{54}$ & & & \\
\hline
\end{tabular}

Source: Regression Data Analysis (2017)

Table 9: Pooled regression (before and after IFRS adoption for CSHFLW)

Dependent Variable: TC

Method: Ordinary Least Square (OLS)

Sample: 8YEARS

Included Observation: 54

\begin{tabular}{|c|c|c|c|c|}
\hline $\begin{array}{c}\text { Variabl } \\
\text { e }\end{array}$ & Coefficient & $\begin{array}{l}\text { Std. } \\
\text { Error }\end{array}$ & $\begin{array}{c}\mathrm{T}- \\
\text { Statisti } \\
\mathrm{c}\end{array}$ & Prob \\
\hline $\mathbf{T C}$ & -4207.326 & $\begin{array}{c}1943.20 \\
1\end{array}$ & -2.165 & 0.302 \\
\hline RI & $1.952 \mathrm{E}-005$ & 0.000 & 1.893 & 0.221 \\
\hline & $0.612^{a}$ & $\begin{array}{c}\text { Mean } \\
\text { depende } \\
\text { nt Var }\end{array}$ & & 259.6 \\
\hline $\begin{array}{c}\text { Adjuste } \\
\text { d R }^{2}\end{array}$ & 0.374 & $\begin{array}{c}\text { S.D } \\
\text { Depende } \\
\text { nt Var }\end{array}$ & & $\begin{array}{c}37.59 \\
7\end{array}$ \\
\hline$R S S_{3}$ & $\begin{array}{c}64736517.9 \\
95\end{array}$ & $\begin{array}{l}\text { Durbin- } \\
\text { Watson } \\
\text { Statistics }\end{array}$ & & 0.895 \\
\hline$F$ & 3.585 & & & \\
\hline d. $f$ & 6 & & & \\
\hline $\mathbf{N}$ & 54 & & & \\
\hline
\end{tabular}

Source: Regression Data Analysis (2017)

To compute the Chow Test using the formula thus;

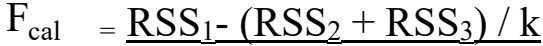

$$
\mathrm{RSS}_{2}+\mathrm{RSS}_{3} / \mathrm{n}-2 \mathrm{k}
$$


( )- t-value, RSS - Residual Sum of Squares, ** $(\mathrm{p}<0.05)-$ significant at $\alpha=0.05$

The tables above shows that;

Sum of Square residual for periods before and after IFRS adoption $=64736517.995$

Sum of Square residual for periods before IFRS adoption $=32321435.967$

Sum of Square residual for periods after IFRS adoption $=655.460$

Following the $F$ distribution with $(\mathrm{n}-2 \mathrm{k}) \mathrm{df}$ in the numerator and the denominator respectively, in this study, $k=2$, since there are only two parameters in each sub-regression and $\mathrm{n}=\mathrm{n}-2 \mathrm{k}=54-4=50$

Therefore,

$$
\begin{aligned}
\mathrm{F}_{\mathrm{cal}} & =\frac{\mathrm{RSS}_{1}-\left(\mathrm{RSS}_{2}+\mathrm{RSS}_{3}\right) / \mathrm{k}}{\mathrm{RSS}_{2}+\mathrm{RSS}_{3} / \mathrm{n}-2 \mathrm{k}} \\
& =\frac{64736517.995_{1}-\left(32321435.967_{2}+655.4600_{3}\right) / 2}{32321435.967_{2}+655.460 / 54-2 \times 2}
\end{aligned}
$$$$
=\underline{64736517.995-32322091.4 / 2}
$$$$
32322091.4 / 50
$$$$
=\underline{32414426.6}
$$$$
646441.828
$$$$
=50.1428
$$$$
\mathrm{F}_{\mathrm{tab}}=\mathrm{F}_{\alpha,}\left[\mathrm{k},\left(\mathrm{n}-2_{\mathrm{k}}\right)=\mathrm{F} 0.05,[2,6]=5.143\right.
$$

From the results Chow Test computed above, at $\alpha=0.05, F_{\text {cal }}=50.1428>F_{\text {tab }}=5.143$ at $(2,6)$ degree of freedom. We therefore accept the alternative hypothesis $\left(\mathrm{H}_{1}\right)$ and conclude that there is a structural change on cash flow after adoption of IFRS on 0.05 level of significance. This implies that since adoption of IFRS in the firms at 0.05level of significance there are changes in the cash flow. We therefore conclude that the adoption of IFRS has significantly improved the cash flow in determining market price of manufacturing companies in Nigeria.

\section{Discussion of Findings}

Book value per share: In test of this hypothesis in order to determine structural break/ change, the study discovered that book value per share F-table value is $=8.5373>$ F-critical value $=5.1433$, showing that the adoption of IFRS has significantly improved the book value per share in determining market price of manufacturing companies in Nigeria.
This finding therefore supports our prior expectation and the findings of Elbakry, Nwachukwu, Abdou and Elshandidy (2016); Charumathi and Suraj (2015); Latifat (2015); Adebimpe and Ekwere (2015); Adaramola and Oyerinde (2014); Nyabundi (2013) Tharmila and Nimalathasan (2013); Babalola (2012); Halonen, Parlovic and Pearson (2012); Ben Naceur, and Nachi (2007); and negates the view of Mwila (2015); Omokhudu and Ibadin (2015); Sharma, Singh and Kumar (2012); . Olga and Veltri (2012); Rahman (2012); Aleksanyan (2007); Mingyi (2000).

Earnings Per Share: In test of this hypothesis in order to determine structural break/ change, the study discovered that earnings shows F-table value $=9.2107$ $>$ F-critical value $=5.1433$, showing that the adoption of IFRS has significantly improved earnings per share in determining market price of manufacturing companies in Nigeria. This finding therefore supports our aprori expectation and the findings of Elbakry, Nwachukwu, Abdou and Elshandidy (2016); Mwila (2015); Latifat (2015); Omokhudu and Ibadin (2015); Adebimpe and Ekwere (2015); Adaramola and Oyerinde (2014); Nyabundi (2013); Tharmila and Nimalathasan (2013); Babalola (2012); Rahman (2012); Karunarathne and Rajapakse (2010); Ben Naceur, and Nachi (2007); Ayed and Abaoub (2006); Mingyi (2000) and negates the view of Charumathi and Suraj (2015); Halonen, Parlovic and Pearson (2012); Olga and Veltri (2012); Habib and Elhamaney (2009);

Cash flow: In test of this hypothesis in order to determine structural break/ change, the study discovered that cash flow F-table value $=50.1428>\mathrm{F}$ critical value $=5.1433$ ), showing that the adoption of IFRS has significantly improved the cash flow in determining market price of manufacturing companies in Nigeria. Omokhudu and Ibadin (2015); Adaramola and Oyerinde (2014); Dimitropoulos, Asteriou and Koumanakos (2010); Habib and Elhamaney (2009); Ben Naceur, and Nachi (2007); and negates the view of Olga and Veltri (2012); Ayed and Abaoub (2006).

\section{SUMMARY OF FINDINGS, CONCLUSION AND RECOMMENDATIONS \\ Summary of Findings}

Based on the analysis and results from the data tested, the study stated the following findings;

1. The adoption of IFRS has significantly improved the book value per share in determining market price of manufacturing companies in Nigeria. The 
statistical test showed that higher book value per share in post-IFRS than pre-IFRS.

2. The adoption of IFRS has significantly improved the Earnings Per Share in determining market price of manufacturing companies in Nigeria. The statistical result indicates that there is a structural change in Earnings Per Share as a result of IFRS adoption.

3. The adoption of IFRS has significantly improved the cash flow in determining market price of manufacturing companies in Nigeria. The test showed that there is a structural change in cash flow as a result of IFRS adoption.

\section{Conclusion}

The result of the change in accounting regulations is as weaknesses of NGAAP and low disclosure requirements. From all indication, there is an improvement on the book value per share, market value per share, earnings per share and cash flow of the Nigerian manufacturing companies' couple with the adoption of IFRS. This showed that the value relevance of accounting information after the adoption of IFRS.

Although the value relevance of accounting information has been studied in many perspectives, some related studies has offered contradicting results about whether relevance of accounting information has declined or increased over time. Some empirical studies reveal that value relevance of accounting information declines, many studies found that value relevance of accounting numbers increases. Many countries' results show that adopted IFRS significantly improve value relevance of accounting information. Therefore, this study is consistent with the studies that revealed an increase in the value relevance of accounting information after implementation of IFRS.

\section{Recommendations}

Based on the findings of this research work, the study recommends thus;

1. The accounting information for book value per share should be communicated to the investing public; and such information should be of high quality to avoid negative consequences on the part of investors.

2. Investors should have it in mind that earnings represent quite a significant variable in the determination of share prices. Therefore earnings per share should be given high consideration during the investor decision making process.

3. The accounting preparers and standard setters should enhance the quality of cash flow because it received attention of most investors as it disclose the in and out movement of cash for operations.

4. However, potential investors in Nigeria should consider manufacturing firms while making investments decision.

\section{Implication of the Findings}

The findings of this study imply that the value relevance of accounting information of manufacturing companies is more sensitive during Post-IFRS era than the Pre-IFRS era. This may also imply that the book value per share, market price, earnings and cash flow have become informative to equity investors in determining the value of firms following IFRS adoption.

\section{Contributions to Knowledge}

In addition to the statistical tools used by previous studies, this research contributes to the literature by adding additional statistical tool (Chow test) in determining whether the structural change has a measurable effect on the study periods. This however, has provided a clearer view to the study on IFRS and value relevance of accounting information on the Nigerian manufacturing firms.

\section{References}

1. =6 Abiodun, B., Y., (2012). Significance of accounting information on corporate values of firms in Nigeria. Research journal in organizational psychology \& educational studies 1(2) 105-113, pp. 105 - 113.

2. Aboody, D., Hughes, J., \& Liu, J. (2002). Measuring value relevance in a (possibly) inefficient market. Journal of Accounting Research, 40(4), 965-986.

3. Abdulkadir, M. (2013). Adoption of international reporting standard in developing economy," International Journal of Business Management, 7(3) pp. 152-161.

4. Abubakar, S., (2010) Value Relevance of Accounting Information of Listed New Economy Firms in Nigeria: An Empirical Investigation using Ohlson Model.

5. Abubakar, S. (2015). Intangible assets and value relevance of accounting information of listed 
high-tech firms in Nigeria. Research Journal Of Finance and Accounting.6(11), 2015 ISSN 2222-1697 (Paper) ISSN 2222-2847 (Online

6. Abata, M. A. (2015). Impact of IFRS on financial reporting practices in Nigeria. Global journal of contemporary research in accounting, auditing and Business Ethics (GJCRA). An Online International Research Journal 1(1) (ISSN: 2311-3162) www.globalbizresearch.org.

7. Adaramola A. O. \& Oyerinde, A. A. (2014). Value relevance of financial accounting information of quoted companies in Nigeria: A Trend Analysis. Research Journal of Finance and Accounting, ISSN 2222-1697 (Paper) ISSN 2222-2847 (Online)5(8), 2014.

8. Adaramola A. O. \& Oyerinde, A. A. (2014). The relationship between financial accounting information and market values of quoted firms in Nigeria. Global journal of contemporary $r$ bbbbesearch in accounting, auditing and business ethics (GJCRA) An Online International Research Journal (ISSN: 23113162) 1 (1)

9. Adebimpe O. U. \& Ekwere R. E. (2015).IFRS adoption and value relevance of financial statements of Nigerian listed $R$ banks. International Journal of Finance and Accounting 2015, 4(1): 1-7 DOI: 10.5923/j.ijfa.20150401.01.

10. Akintoye, R. I. (2008). Optimising investment decision through informative accounting reporting" European Journal of social sciences, 7(3). 27-41.

11. Armstrong, C. S., Barth, M. E., Jagolinzer, A. D., \& Riedi, E. (2010). Market reaction to the adiption of IFRS in Europe. The Accounting Review, 85 (1) (January): 31-61.

12. Alali, F. A. \& Foote, P. S. (2008). EarningsReturns Association in an Emerging Market: An Empirical Analysis of Abu Dhabi Securities Market, California State University Fullerton Southeast AAA Conference April 3

13. Aleksanyan, M. (2007). Valuation and value relevance of the firm-level, and geographic and business segment-level accounting information. Ph.D. Thesis, University of Glasgow, United Kingdom, 1-429.
14. Amir, E., Harris, T., \& Venuti, E. (1993). A comparison of the value-relevance of US versus non-US GAAP accounting measures using form $20 \mathrm{f}$ reconciliations. Journal of Accounting Research, 31 , 230-264. http://dx.doi.org/10.2307/2491172.

15. Asian, A. U., (2015). IFRS adoption and firms' performance: a comparative analysis of quoted food and beverage manufacturing firms in Nigeria. European journal of accounting auditing and finance research 3(8) pp.77-90, august 2015.

16. Asein, A. A. (2011). International financial reporting standards; Imperatives of the new financial reporting framework. The Nigerian Accountant, October/ December, 44(4), 16-25.

17. Ayed, M. R., \& Abaoub, E. (2006). Value relevance of accounting earnings and the information content of its components: Empirical evidence in Tunisian Stock Exchange, Working Paper, Faculté des Sciences Economiques et de Gestion de Tunis, Université Tunis- El Manar.

18. Ayzer, B.F. \& Cema, I. (2013). Effects of new financial report standards on value relevance. A study of Turkish stock markets. International Journal of Economics and Finance. 5(10)10-13. http://ccsenet.org/journal/index.php/ijef/article/v iewFile/30676/18065.

19. Babalola Y. A. (2012). Significance of accounting information on corporate values of firms in Nigeria. Research Journal in Organizational Psychology \& Educational Studies 1(2) 105-113. www.emergingresource.org.

20. Babalyan, L. (2001). Association between accounting earnings and stock returns as measure of value relevance of accounting standard: empirical evidence from Swiss market." EFA Berlin Meetings, Discussion paper.

21. Barth, M., Landsman, W. \& Lang, M. (2007). International accounting standards and accounting quality. Journal of accounting research, 46(3), 146-498.

22. Barth, M. E., Beaver, W. H. \& Landsman, W. R. (1998). Relative Valuation Roles of Equity Book Value and Net Income as a Function of 
Financial Health. Journal of Accounting and Economics 25: 1-34.

23. Barth, M. E., \& Beaver, W. H. (2000). The Relevance of value relevance research. In Journal of accounting \& economics conference (pp. 1-41).

24. Barth, M. E., Cram, D. P., \& Nelson, K. K. (2001). Accruals and the prediction flows of future cash. American Accounting Association, 76(1), 27-58.

25. Barth, M. E., Gomez-Biscarri, J., \& LopezEspinosa, G. (2012). Fair value accounting and firm valuation. Retrieved July 2, 2014 from: http://pendientedemigracion.ucm.es/centros/cont /descargas/documento18505.pdf

26. Baltariu, C.A. (2015). The current state of knowledge in the value relevance research field. SEA - Practical Application of Science, Volume III, Issue 1 (7) / 2015.

27. Bao, B. H \& Bao, D. H. (2004). Value Relevance of Operating Income Versus Nonoperating Income in the Taiwan Stock Exchange, Advances in International Accounting, 17(1), 103-117.

28. Bello, A. (2009). The fallacy of income and income measurement in accounting. Journal of Accounting Research, 2 (1), 15-31.

29. Ben, N. \& Nachi, W. (2007). Does the Tunisian accounting reform improve the value relevance of financial information? Afro-Asian Journal of Accounting and Finance, 20 (3). (www.inderscience.com).

30. Belkaoui, A. R. (2004). Accounting theory (4 ${ }^{\text {th }}$ edition). United Kingdom: T. J. International.

31. Benston, G. J. (2007). Contemporary issues in financial reporting: a user-oriented approach. The International Journal of Accounting, February, 23-32.

32. Beaver, (2002). Perspectives on recent capital market research", accounting review vol 77, 453-474.

33. Be island, L. A. (2009). A Review of the value relevance literature. The open business journal, 2(1), 7-27.Doi:10.2174/1874915100902010007.

34. Beijer, D., Dekimpe, M., Dutordoir, M., \& Verbeeten, F. H. M. (2008). The impact of brand value announcement on firm value. Rotterdam,
Netherland: Rotterdam School of Management, Erasmus University.

35. Belesis, N. \& Sorros, J (2010). Value Relevance of earnings and book value for Greek listed firms.

36. Bischof, J. (2009). The Effects of IFRS 7 adoption on bank disclosure in Europe. Accounting in Europe, 6(2), 167-194. Doi: 10.1080/17449480903171988.

37. Brown, S. Lo, K. \& Lys, T. (1999). Use of R2 in accounting research: measuring changes in value relevance over the Last Four Decades. Retrieved June 20, 2007 from http:// www.Sirca.org.uk.

38. Carazavan-Jeny, A. \& Jean-Jeny, T. (2003). Value relevance of $R \& D$ reports: $A$ signalling interpretation. Working paper 2003-12, CEREG, University of Paris.

39. Chen J. P.; Chen S. \& Su X. (1999. Is Accounting Information Value Relevant in the Emerging Chinese Stock Market? Journal of International Account. Audit and Taxation. 10:1-22

40. Chen, C, Chen, S., \& Su, X. (2001). Is accounting information value relevant in the emerging Chinese stock market? Journal of International Accounting Auditing \& Taxation, $10(1), 1-22$.

41. Cheng, L. H., \& Fan, H. K. (2010). Drivers of environmental disclosure and stakeholder expectation: evidence from Taiwan. Journal of Business Ethics, 96, pp. 435-451. http://dx.doi.org/10.1007/s10551-010-0476-3

42. Charumathi, B., \& Suraj, E. S. (2015). Value relevance of earnings and book value for bank stocks - An empirical analysis using Ohlson valuation model. Global journal of management and research.

43. Choi, H. S., \& Jang, I. J. (2006). The relative value relevance of earnings and cash flows measures in each life-cycle stage. Korean Management Review, 35(1), 1339-1360.

44. Collins, D. W., Maydew, E. L., \& Weiss, I.S. (1997). Changes in the value relevance of earnings and book values over the past forty years, journal of accounting and economics, 24(1), 39-68. http://dx.doi.org/10.1016/S01654101 (97)00015-3. 
45. Conceptual Framework for Financial Reporting. (2010). September.

46. Cunningham, G. M., \& Harris, J. E. (2006). Enron and Arthur Andersen: The case of the Crooked E and the Fallen A. Global Perspectives on Accounting Education, 3, 27-48.

47. Dhaliwal, D., Subramanyan, K. R. \& Trezevant, R. (1999). Is comprehensive income superior to net income as a measure of firm performance?" Journal of accounting and economics, 26: 4367.

48. Donaldson, T, \& Preston, L.E. (1995). The stakeholder theory of the corporation: concepts, evidence, and implications. The Academy of Management Review, 20(1): 65-91.

49. Deegan, C. (2001). Financial accounting theory. Roseville, NSW: McGraw-Hill Book Company Australia Pty Limited.

50. Dimitropoulos, P. E., Asteriou, D., \& Koumanakos, E. (2010). The relevance of earnings and cash flows in a heavily regulated industry: Evidence from the Greek banking sector. Advances in Accounting, 26(2), 290-303. doi:10.1016/j.adiac.2010.08.005.

51. Daske, H. Hail, C. \& Leuz, V. (2006). Mandatory IFRS reporting around the world: Early evidence on economic consequences," Journal of Accounting and Research, vol. 46(5) pp. 1085-1142.

52. Dumontier, P. \& Raffornier, B. (2002). Accounting and capital markets: a survey of the European Evidence. " The European Accounting Review, 11(1), 119-151

53. Ebaid, I. E. (2012). The value relevance of accounting-based performance measures in emerging economies. The case of Egypt, 35(1), 69-88. Doi: 10.1108/01409171211190814.

54. Elbakry, A. E., Nwachukwu,J. C.,. Abdou, H .A., \& Elshandidy, T. (2016). Comparative evidence on the value relevance of IFRS-based accounting information in Germany and the UK. Journal of International Accounting, Auditing and Taxation 28 (2017) 10-30

55. Ernst \& Young (2012). Australia Switch to International Financial Reporting Standards. A Perspective from Accounting and Finance. Accounting and Finance Journal, 46, 629-652.
56. Fact book (2014). Nigeria Statistics [Online] Available:

https:/www.cia.gov/library/publications/theworld-factbook/geos/ni.html.

57. FASB (1978). Objectives of financial reporting: Concepts statement No. 1. FASB: Business Stamford, CT.

58. FASB (1980). Qualitative characteristics of accounting information: Concepts statement No. 2. FASB: Stamford, CT. FASB (1985). Elements of financial statements: Concepts statement No. 6. FASB: Stamford, CT.

59. Fasina, H. T \& Adegbite. T. A. (2014). Empirical analysis of the effect of international financial reporting standard (IFRS) adoption on accounting practices in Nigeria". Acrhives of business research. [On- lime] 2(2). Pp.1-14. Doi:10.14738/abr.22.43. March 6

60. Francis \& Schipper. K., (1999). How Financial Statements lost their Relevance". Journal of Accounting Research [On-lime]. 37. Pp. 319353. March 6.

61. Freeman, R. E. (1984). Strategic management: a stakeholder approach. USA: Pitman Publishing Inc.

62. Freeman, R. E., Harrison, J.E., \& Wick, A. C. (2007). Managing for stakeholders: survival, reputation and success. New Heaven, CT: Yale University Press.

63. FRCN (2011). Financial Reporting Act. Federal Republic of Nigeria Official Gazette 54(98).

64. Geijsbeek, J. B. (1914). Ancient Double-Entry Bookkeeping: Lucas Pacioli's Treatise. Denver: University of Colorado.

65. Gaston, S. C., Fernadez, B. C., Harne J. I., \& Gadea, J. A. L. (2003). The valuation of earnings components by the capital markets: An International Comparison. Documento de Trabajo.

66. Glezakos, M., Mylonakis, J., \& Kafouros, C. (2012). The impact of accounting information on stock prices: evidence from the Athens Stock Exchange. International journal of economics and finance, 4(2), 56-68.

67. Ghayoumi, A. F., Nayeri, M. D., Ansari, M. \& Raeesi, T. (2011). Value relevance of accounting information: Evidence from Iranian 
emerging stock market. Word Academy of Science, Engineering and Technology 78.

68. Ghofar, A. \& Saraswati, E. (2008). Problems in financial reporting: the analysis of quality of disclosure and the measurement system of the traditional accounting. Retrieved on 28/11/2010 from http://www.indonesiauniversity.edu.in/

69. Gjerde, O., Knivsfla, K. \& Saettem, F. (2005). The value relevance of financial reporting on the Oslo stock exchange over the period 1964-2003. Discussion paper 2005/23, department of finance and management science, Norwegian school of economics and business administration.

70. Gjerde, O., Knivsfla, K. \& Saettem, F. (2007). The value-relevance of financial reporting in Norway. 1965- 2004, Working Paper, February. www.iaabd.org/2009_iaabd_proceedings/track1 b.pdf, retrieved on 15 December, 2010.

71. Gleason, K. I. \& Klock, M. (2006). Intangible capital in the pharmaceutical and chemical industries. Working Papers 1999-2006, paper 10. Yale University: Department of Economics and Finance.

72. Godfrey, J. M Hodgson, A. Tarca, A. Hamilton, J. \& Holmes, S(2010). Accounting Theory, Milton, Qld.: John Wiley, 2010.

73. Goodwin, J. \& Ahmad, K. (2006). Longitudinal value relevance of earnings and intangible assets: Evidence from Australian firms. Journal of International Accounting, Auditing \& Taxation 15, 72-91.

74. Graham, R. C., King, R. D. \& Bailes, J. C. (1998) the Value Relevance of Accounting Information in Thailand around the 1997 Decline in the Value of the Baht. Available at SSRN: http://ssrn.com/abstract $=138148$ or doi:10.2139/ssrn.138148, retrieved on 26 August, 2010.

75. Gray, R., Owen, D. \& Adams, C. (1996). Accounting and Accountability, Prentice-Hall, Englewood Cliffs, NJ.

76. Habib, W. M \& Elhamawy, S. M. (2009). On the value relevance of finance cash flows and accounting accruals: empirical evidence from Egypt. Ains Shams University Journal of Economic studies. 3, 1-22.
77. Halonen, E., Pavlovia, J., \& Pearson, R. (2013). Value relevance of accounting information and its impact on stock prices: Evidence from Sweden. Department of /economics Stockholm University abstract: Final version of value relevance of act data evidence. Retrieved 16th December, 2014.

78. Herbert, N. E., Isegba, I. N., Ohalede, A. C. \& Anyahara, I. O. (2013). Adoption of IFRS: Insight from Nigerian Academics and Practitioners. Research journal of financial accounting. 4(6): 121-135.

79. Hati, W. J., \& Rakshit, D. (2002). Integrating accounting standards: A step towards harmonization. Management accountant, ICWAI, May 2002.

80. Holthausen, R. W., \& Watts, R. L. (2001). The relevance of the value relevance literature for financial accounting standard setting. Journal of Accounting \& Economics. 31(3), 3-75. http://dx.doi.org/10.1016/S01654101(01)00029-5.

81. Hellstrom, K. (2006). The value relevance of financial information in a transition economy: The case of the Czech Republic. European Accounting Review, 15(1), 325-349.

82. Isabel, S. \& Mariela, I. (2009). Implementation of IFRS for non- financial companies and its impact on financial stability and monitoring at the Central Bank of Chile," Central Bank of Chile, SDFP, pp. 1-26, 2009.

83. Institute of Chartered Accountant of Nigeria (ICAN). (2014) Management, governance and ethics. United Kingdom: Emile woolf international, pp. 290-298.

84. Inwinkl, P. (2010). Reclassification of financial instruments in the nordiccounties," M.S. thesis, Jonkoping International Business School.

85. Isenmila, P. A. \& Adeyemo, K. A. (2013). A perception based analysis of the mandatory adoption of IFRS in Nigeria. Research journal of finance and accounting. 3(10). 143-151.

86. Ikpefan, O. A. \& Akande, A.O (2012). International financial reporting standard (IFRS): benefits, obstacles and intrigues for implementation in Nigeria. Business Intelligence Journal. 5(2) 
International Journal of Trend in Scientific Research and Development (IJTSRD) ISSN: 2456-6470

87. Jackson, A. (2008). Are there unrecorded advertising intangible assets in the valuation gap? Journal of Accounting and Economics, 37, 33-55.

88. Jayeoba, O. O. \& Ajibade, A. T.(2016). Evolution of accounting standards in Nigeria: A Historical Perspective. International journal of advanced academic research | social \& management sciences | ISSN: 2488-9849 2(8).

89. Jensen, R. E. (2007). Fair value accounting in the USA. In P. Walton, the Rout ledge Companion to Fair Value and Financial Reporting. Oxon: Rout ledge.

90. Jennings, R., Mac, J. L. \& Thompson, R. B.(1997). Evidence on the usefulness of alternative earnings per share measures. Financial Analysts Journal, 36-46

91. Jinadu, O. (2016). The adoption of IFRS and value relevance of accounting information in Nigeria. International Journal of Innovative Research and Advanced Studies (IJIRAS) 3(4).

92. Jones, D. A. \& Smith, K. J. (2011). Comparing the value relevance, predictive value, and persistence of other comprehensive income and special items. The Accounting Review: November 2011, 86(6) pp. 2047-2073.

93. Jonna, W. (2009).The influence of GFRS implementation on business management," M.S. thesis, Helsinki school of Economics, 2009

94. Josiah, M., Okoye, A. E., \& Adediran, O. S. (2013). Accounting standards in Nigeria, the journey so far. Research Journal of Business Management and Accounting, Vol. 2(1), 001010.

95. Kaaya, I. D. (2015). The International Financial Reporting Standards (IFRS) and Value Relevance: A Review of Empirical Evidence. Journal of Finance and Accounting, 2015, 3(3) 37-46 Available online at http://pubs.sciepub.com/jfa/3/3/1 (C) Science and Education Publishing DOI:10.12691/jfa-3-3-1

96. Khanna M., (2014). value relevance of accounting information: an empirical study of selected Indian Firms International Journal of Scientific and Research Publications, 4(10), October 20141 ISSN 2250-3153 www.ijsrp.org

97. Kargin, S. (2013). The impact of IFRS on the value relevance of accounting information: evidence from Turkish firms. International Journal of Economics and Finance, 5(4), 71-80. doi:10.5539/ijef.v5n4p71.

98. Karunarathne, W, \& Rajapakse, R., (2010). Value Relevance of financial statement information: with special reference to the listed companies in Colombo stock exchange, University of Kelaniya, Srilanka.

99. Kehinde, J. S (2012). Share price change: the efficient market hypothesis and the white noise hypothesis dichotomy. Internal Journal of Humanities and Social Science, 2(22), 195-200.

100. Keener, M.H. (2011). The Relative value relevance of earnings and book values across industries, Journal of Finance and Accountancy, $1-19$.

101. Khanagha, J. B., Mohamad, S., Hasssan, T. \& Sori, Z. M. (2011). The impact of reforms on the value relevance of accounting: Evidence from Iran. African Journal of Business Management, 5(1), 96-107.

102. Kirkulak \& Balsari. (2009). Value relevance of inflation adjusted equity and income. The international journal of Accountng. 44, 363-377. http://dx.doi.org/10.1016/j.intacc.2009.09.007.

103. Kipchoge, K. A. (2015). Effect of corporate attributes on international financial reporting standard disclosure level: Evidence from Kenya listed firms". Research journal of finance and accounting. [On-lime] 6(1):97-107. March 6

104. Klimczak, K.M. (2009). Testing Value Relevance of Accounting Earnings in Emerging Markets,http://kmklim.republika.pl/ekonomia/re source/kmklimczak_GAT_2008.pdf, retrieved 26 August, 2010.

105. Kothari, S. P. \& Sloan S. G. (1992). Information in Prices about Future Earnings." Journal of accounting Economics 15 (23), 143-71.

106. Kasum, A. S. (2007).The impact of compliance with accounting standards on assets and profitability of Nigerian quoted companies," Journal of Commerce, vol. 3, no. 3, pp. 56-68, 2011.

107. Kwon, J. G. (2009). The value relevance of book values, earnings and cash flows: Evidence from Korea. International Journal of Business and Management, 4(10), 28-42. 
International Journal of Trend in Scientific Research and Development (IJTSRD) ISSN: 2456-6470

108. Lamberg, E. (2004). Income measurement: Some comments. Estonia: Estonia Business School.

109. Latifat, M. (2015). International financial reporting standard and value relevance of accounting information in quoted cement firms in Nigeria. International Journal of Sciences: Basic and Applied Research (IJSBAR) (2015) Volume 22, No 1, pp 81-95.

110. Lawani, I. R., Umanhonlen, O. F. \& Okolie. R. O. (2015). Conservatism and value relevance of accounting information in quoted firms in Nigeria". International journal of finance and accounting. [On-lime]. 4(1), pp.21-39. Doi:10.5923/j.ijfa.20150401.03. March 6

111. Lepineux, F. (2004). Stakeholder Theory, Society and Social Cohesion. Centre for the Management of Environmental and Social Responsibilities (CMER) - INSEAD, Working Paper Series, pp. $1-20$.

112. Lee, C., \& Park, M. S. (2013). Subjectivity in fair-value estimates, audit quality, and in formativeness of other comprehensive income. Advances in Accounting, 29(2), 218-231. doi:10.1016/j.adiac.2013.05.003

113. Lee, K, J., \& Huh, S-K. (2010). Firms financial leverage and its impact on differential roles of earnings and book value for equity valuation. Pan-Africa Journal of Business Research, 1(1), 41-59.

114. Leonard L. \& Jan, S. (2012). IFRS enforcement and their role for accounting quality and comparability," M.S. thesis, Stockholm School of Economics, 2012.

115. Lev, B., \& Zarowin, P. (1999). The boundaries of financial reporting and how to extend them, Journal of Accounting Research, 37(2): 353385. http://dx.doi.org/10.2307/2491413.

116. Livant, J. \& Segal, D. (2000). The calculation of earnings per share and market value of equity: Should common stock equivalents be included?

117. Lev, B., \& Zarowin, P. (1999). The boundaries of financial reporting and how to extend them, Journal of Accounting Research, 37(2): 353385. http://dx.doi.org/10.2307/2491413.

118. Marris, R., \& Singh, A. (1966). A measure of a firm's average share price, Journal of the Royal Statistical Association, Series A, 129, 74-97.
119. Mao, C. (2006). Is the Value Relevance of Earnings Information Really Decreasing Over time?" Retrieved at: ifas.xmu.edu.cn/pic/201012/21/2010122110683 96.pdf

120. Manuel, H. (2008). How to hedge disclosure, Research thesis, Department of Accounting, Handelshogokolan University, Spain, 2008.

121. Melissa, A. N. (2013). Value relevance of financial statements information: evidence from listed firms in kenya. Advances in Management \& Applied Economics, 3(1), 2013, 115-134 ISSN: 1792-7544 (print version), 1792-7552 (online).

122. Meyer, C., (2007). Shareholder value accounting-the value relevance of financial statements data and the determinants of accounting methods choices", http://www.research.unizh.ch. (08.03.2010).

123. Mechelli, A., \& Cimini, R. (2014). Is Comprehensive Income Value Relevant and Does Location Matter? A European Study. Accounting in Europe, 16(25), 1-35. doi:10.1080/17449480.2014.890777

124. Mingyi, H. (2000). Accounting standards and value relevance of financial statement: an international analysis" Journal of Accounting Economic 30:401-20.

125. Modigliani, F. \& Miller, M. (1959), The Cost of Capital Corporate Finance and the theory of Investment. American economic Review, 48: 261-297.

126. Menaje, P. M. (2012). Impact of selected financial variables on share price of publicly listed firms in Philippines. American international journal of contemporary research, 2(9), 98-104.

127. Millar, J. A., Nunthirapakorn, T. \& Courtney, S. (1987). A note on the information content of primary and fully diluted earnings per share. Financial Analysts Journal,77-79.

128. Maines, L. \& Wahlen, J. (2006). The nature of accounting information reliability: inferences from archival and experimental research. Accounting Horizons, 20 (4), 399-425.

129. Mattessich, R. (1989). Accounting and the Input-Output Principle in the Prehistoric and Ancient World. Abacus, 25(2), 78 -84. 
International Journal of Trend in Scientific Research and Development (IJTSRD) ISSN: 2456-6470

130. Mwila, J. M., (2015). Value Relevance of Accounting Information of Listed Public Sector Banks in Bombay Stock Exchange. Research Journal of Finance and Accounting 6(8) ISSN 2222-1697 (Paper) ISSN 2222-2847 (Online) www.iiste.org

131. Nassar, L. M. Uwuigbe, O. R. \&. Abuwa. J. T (2014). IFRS adoption and its intergration into accounting education curriculum in Nigerian Universities". Research journal of finance and accounting. [On-lime]. 5(22), pp.76-82.March 6

132. NASB (2010). Report of the committee on road map to the adoption of IFRS. [Online] Available: $\quad$ www.financialreporting council.gov.ng/.../Roadmap $\% 20 \longrightarrow$ Final $\%$ 20Report.

133. Nasi, J., Nasi, S., Philip, N., \& Zylidopoulos, S. (1997). The evolution of corporate social responsiveness- an exploratory study of Finnish and Canadian forestry companies. Business \& Society, 38(3), 10 pp. 296-321. http://dx.doi.org/10.1002/bse.427

134. NSE (2014). Market capitalization. [Online] available:

http://www.nse.com.ng/Pages/default.aspx?c=M ARKCAP.

135. Nirmala, N. \& Florence, J. (2011). Value relevance of accounting information". Journal. Finance \& Account Management. 2,(1), 16-26.

136. Ndubizu, G. A. \& Sanchez, M. (2004). The valuation properties of earnings and book values prepared under US GAAP in Chile and IAS in Peru. International Journal of Accounting, 55; 235-52.

137. Ng, A.C., Gul, F.A. \& Mensah, Y.M. (2007). Managerial entrenchment and value relevance of earnings during the preand post-Sarbanes Oxley periods.

138. Nikhil, C. S., Bhagaban, D., \& Alok, K. P. (2009). Harmonization of accounting standards through internationalization. International Business Research, 2(2), 194-201.

139. Nyabundi, M. A. (2013). Value relevance of financial statements information: evidence from listed firms in Kenya. Advances in Management and Applied Economics, Vol. 3 (1) 115-134, Scienpress Ltd.
140. Ohlson, J.A. (1995), Earnings, book values and dividends in equity valuation, Contemporary Accounting Research, 11 (2), 661-687. http://dx.doi.org/10.1111/j.1911-

3846.1995.tb00461.x

141. Olga, F. \& Veltri, S. (2012). A critical analysis for the empirical researches on comprehensive income value relevance. European Journal of scientific research. 76(4) 587-594.

142. O’Hara, T., Lazdowski, C., Moldovean, C. \& Samuelson, S. (2000). Financial Indicators of stock performance: West Haven. American Business Review.

143. Ohlson, J. (1995). Earning, book values and dividends in security valuation. Contemporary Accounting.

144. Okafor, C. \& Ogiedu, K. O. (2011). Potential effects of the adoption and implementation of international financial accounting standards (IFRS) in Nigeria. JORIND 9(2) December, 2011. ISSN 1596 - 8308. www.transcampus.org.

www.ajol.info/journals/jorind.

145. Okoye, P. V. C., (2014). Effect of IFRS Adoption on key financial ratio of Nigerian banks. Unpublished PhD Thesis, Chukwuemeka Odumegwu Ojukwu University.

146. Okoye, P. V. C., Okoye, J. F. N. \& Ezejiofor, R., A. (2014). Impact of the IFRS adoption on stock market movement in Nigerian corporate organization. International Journal of Academic Research in Business and Social Sciences September 2014, 4(9) ISSN: 2222-6990.

147. Omaima, A. G. H., Peter, R. Gianluigi G. \& David P. (2008). The value relevance of disclosure: evidence from emerging capital market of Egypt". The international journal of accounting [On-lime]. 44:79-102. Doi:10.1016/j.intacc.2008.12.005.

148. Oyerinde, D. T. (2009). Value relevance of accounting information in emerging stock market in Nigeria. Proceeding of the 10th annual international conference. International academy of African business and development (IAABD), Uganda.

149. Omokhudu, O. O. \& Ibadin, P. O, (2015). The value relevance of accounting information: evidence from Nigeria. 
International Journal of Trend in Scientific Research and Development (IJTSRD) ISSN: 2456-6470

www.sciedupress.com/afr Accounting and Finance Research 4(3) 2015.

150. Omokhudu, O. O., \& Otakefe, J.P. (2005). Accounting information in the petroleum marketing industry. Tropical Focus. 6(3), 173193.

151. Ortega, X. (2006). Reinvestigation of value relevance of earnings, book values and cash flow in security prices over time, retrieved at: ccsenet.org/journal/index.php/ijbm/article/downl $\operatorname{oad} / 3186 / \ldots$

152. Osaze, E. B. (2007).Capital Markets - African and Global, the Bookhouse Company, Lagos.

153. Obazee, J. O. (2011). Issues and challenges of International Financial Reporting Standards (IFRS) adoption for emerging economies. The Nigerian Accountant, October/ December, 44 (4), 26-28.

154. Okaro, S.C. (2002). Accounting standard: The Niger. Experience. Niger. Account., 35(4), 29-31

155. Oshodin, E. \& Mgbame C. O. (2014). The comparative study of value relevance of financial information in the Nigeria banking and petroleum sectors. Journal of Business Studies Quarterly 2014, 6, (1).

156. Oyedele, T. (2011). Seminar on IFRS adoption in Nigeria topic: An overview of IFRS and challenges posed to professionals. The chartered institute of taxation of Nigeria (CITN).

157. Oghoma, R. \& Iyoha, F. (2006). Compliance with accounting standards by quoted insurance companies in Nigeria: An empirical investigation," Journal of Education, 7(2), pp. $18-27$.

158. Palea. V. (2013). IAS/IFRS and financial reporting quality: lesson from the European experience" China journal of accounting and research[On-lime]. 6, pp 247-263. Retrieved from:www.elsevier.com/locate/cjar.

159. Pathirawasam C., (2010). Value Relevance of Accounting Information: Evidence from Sri Lanka, International Journal of Research in Commerce and Management (IJRCM), Vol. 1(8), pp. 13-20.

160. Pourheydari, O., Aflatoon, A., \& Nikbakhat, Z. (2008). The pricing of dividends and book value in equity valuation: The case of Iran.
International Research Journal of Finance and Economics, 13, 1450-2887.

161. Prather-kinsey, J. (2006). Developing countries converging with developed-country accounting standards $\square$ : Evidence from South Africa and Mexico. The International Journal of Accounting, 41, 141-162. doi:10.1016/j.intacc.2006.04.007

162. Perera, R. A. A. S., \& Thrikawala, S. S. (2010). An empirical study of the relevance of accounting information investor's decisions. ICBI, University of Kelaniya, Sri Lanka.

163. Penman, S. (1992). Return to fundamentals. Journal of Accounting, Auditing and Finance research, 11, 661-687.

164. Phang S. O \& Mahzan, N. (2013). The responses of Malaysian public companies to the IFRS convergence," Asian Journal of Business and Accounting, vol. 6, no. 1, pp. 95-120, 2013

165. Ragab, A. A. \& Omiran M. M. (2006). Accounting information. Value relevance and Investors? Behaviour in the Egyptian equity market. Review of accounting and finance 5 (3) 20:279-297.

166. Rahman, A. A., (2012): Value relevance of earnings and book value: evidence from Jordan

167. Ratanajongkol, S., Davey, H., \& Low, M. (2006). Corporate social reporting in Thailand, the news is all good and increasing. Qualitative Research in Accounting \& Management, 3(1), pp.

67-83.

http://dx.doi.org/10.1108/11766090610659751

168. Rice, S. J. (1978). The information content of fully diluted earnings per share. The accounting Reviews 429-438.

169. Ryan, G. S. (2008). Fair Value Accounting: Understanding the Issues Raised by the Credit Crunch. Council of Institutional Investors. Retrieved July 2, 2014 from: http://www.uic.edu/classes/actg/actg593/Readin gs/Fair-value.

170. Sami, H., \& Zhou, H. (2002). A comparison of value-relevance of accounting information in different segments of the Chinese Stock market. Working Paper, Temple University.

171. Sami, H., \& Haiyan, Z. (2004). A comparison of value relevance of accounting information in 
International Journal of Trend in Scientific Research and Development (IJTSRD) ISSN: 2456-6470

different segment of the Chinese Stock Market.

The International Journal of Accounting, 39, 403-

427.http://dx.doi.org/10.1016/j.intacc.2004.08.0 01

172. Sani, S., \& Umar D. (2014). An Assessment of compliance with IFRS framework at first-time adoption by the quoted Banks in Nigeria." Journal of Finance and Accounting 2.3 (2014): 64-73

173. Sharma, A, Kumar, S, \& Singh, R (2012). Value relevance of financial reporting and its impact on stock prices: Evidence from India", South Asian Journal of Management, 19(2), 60- 77.

174. Sanusi, S. L. (2010). The Nigerian Banking Industry: What Went Wrong and the way forward". 1-23. Kano: Bayero University.

175. Schumpeter, J.A. (1942). Capitalism, socialism and democracy, 5th edition. London: George Allen \& Unwin

176. Sibel, K. (2013). The Impact of IFRS on the value relevance of accounting information: Evidence from Turkish Firms. International Journal of Economics and Finance;5, (4); 2013. ISSN 1916-971X E-ISSN 1916-9728 Published by Canadian Center of Science and Education.

177. Suadiye, G. (2012). Value relevance of book value \& earnings under the local GAAP and IFRS: Evidence from Turkey. Ege Akademik Review, 12(3), 301-310.

178. Sulaima L. M. \& Athambawa J.(2013).Value relevance of accounting information: evidence from Sri Lanka. Proceedings of the Third International Symposium, SEUSL: 6-7 July 2013, Oluvil, Sri Lanka.

179. Subramanyam, K. R., \& Wild. J. (2000). Going Concern Status, Earnings Persistence, and In formativeness of Earnings. Contemporary accounting research 13: 251-273

180. Swati, D. M. (2015). A review on the literature of value relevance of financial and accounting variables. The International Journal Of Business \& Management. 3(2). (ISSN 2321 -8916).

181. Tharmila, K. \& Nimalathasan, B. (2013). The value relevance of accounting information and its impact on market vulnerability: a study of listed manufacturing companies in Sri Lanka.
Merit Research Journal of Business and Management 1(2) pp. 030-036, December, 2013

182. Tarca, A. (2004). International Convergence of Accounting Practices: Choosing between IAS and US GAAP. Journal of International Financial Management and Accounting, 15(1), 60-91. doi:10.1111/j.1467-646X.2004.00102.

183. Uthman, A. B. \& Abdul-Baki, Z. (2014). The value-relevance of accounting information in Nigeria: analysts' perception in the IFRS regime. Journal of Accounting and Management JAM 4 (1) (2014).

184. Utami, R. S. \& Noraya. S. (2010). Significance of accounting information in explaining Market and book values: the case of Indonesian banks. International Research Journal of Finance and Economics, 55

185. Uwalomwa U., Agba, L. U., Jimoh, J., Olubukunola, R. U., Rehimetu J. (2017). IFRS adoption and earnings predictability: evidence from listed banks in Nigeria. Banks and Bank Systems, 12(1).

186. Vishnani, S., \& Shah, B. K., (2008). Value relevance of published financial statementsWith special Emphasis on Impact of cash flow reporting", International Research Journal of Finance and Economics, 17, 84-90.

187. Vishnani, S. \& Shah B. (2008). International differences in the relation between financial reporting decisions and value relevance of published financial statements- with Special Emphasis on Impact of Cash Flow Reporting, International Research Journal of Finance and Economics, 17(1), 1450-2887.

188. Vijitha, P. \& Nimalathasan, B. (2014). Value relevance of accounting information and shareprice: A study of listed manufacturing companies in SriLanka" Merit Research Journal of Business and Management 2(1) pp. 001-006, January, $2014 \quad$ Available online http://www.meritresearchjournals.org/fst/index.h tm.

189. Valix, C. \& Peralta, J. (2009). Financial accounting, Volume 2. Manila: GIC Enterprises \& Co.

190. Venkatachalam, M. (1996). Value Relevance of Bank Derivatives Disclosures." Journal of Accounting and Economics, 22:327-355 
International Journal of Trend in Scientific Research and Development (IJTSRD) ISSN: 2456-6470

191. William, J. B., (1968). Accounting information and decision making: some behavioural hypothesis, The Accounting Review, 43(3), 469 -480 .

192. Wulandri, E. R. \& Rahman, A. R. (2004). A cross country study on the quality acceptability and enforceability of accounting standards and the value relevance of accounting earnings." Journal of Accounting Research, 42(2): 304-31.

193. Xiong, Y. (2005). Equity valuation in loss firms. The journal of Theoretical Accounting Research 1(1), 77-88.
194. Yusuf, A. M. \& Nor-Asma, L. (2015). The value relevance of accounting disclosures among Nigerian financial institutions after the IFRS adoption. Mediterranean Journal of Social Sciences MCSER Publishing, Rome-Italy 6(1) January 2015.

195. Zhao, Y. L., \& Zang, W. T. (1999). Empirical research on functional fixation of Chinese Securities Market. Journal of economic research, 9, 56-63.

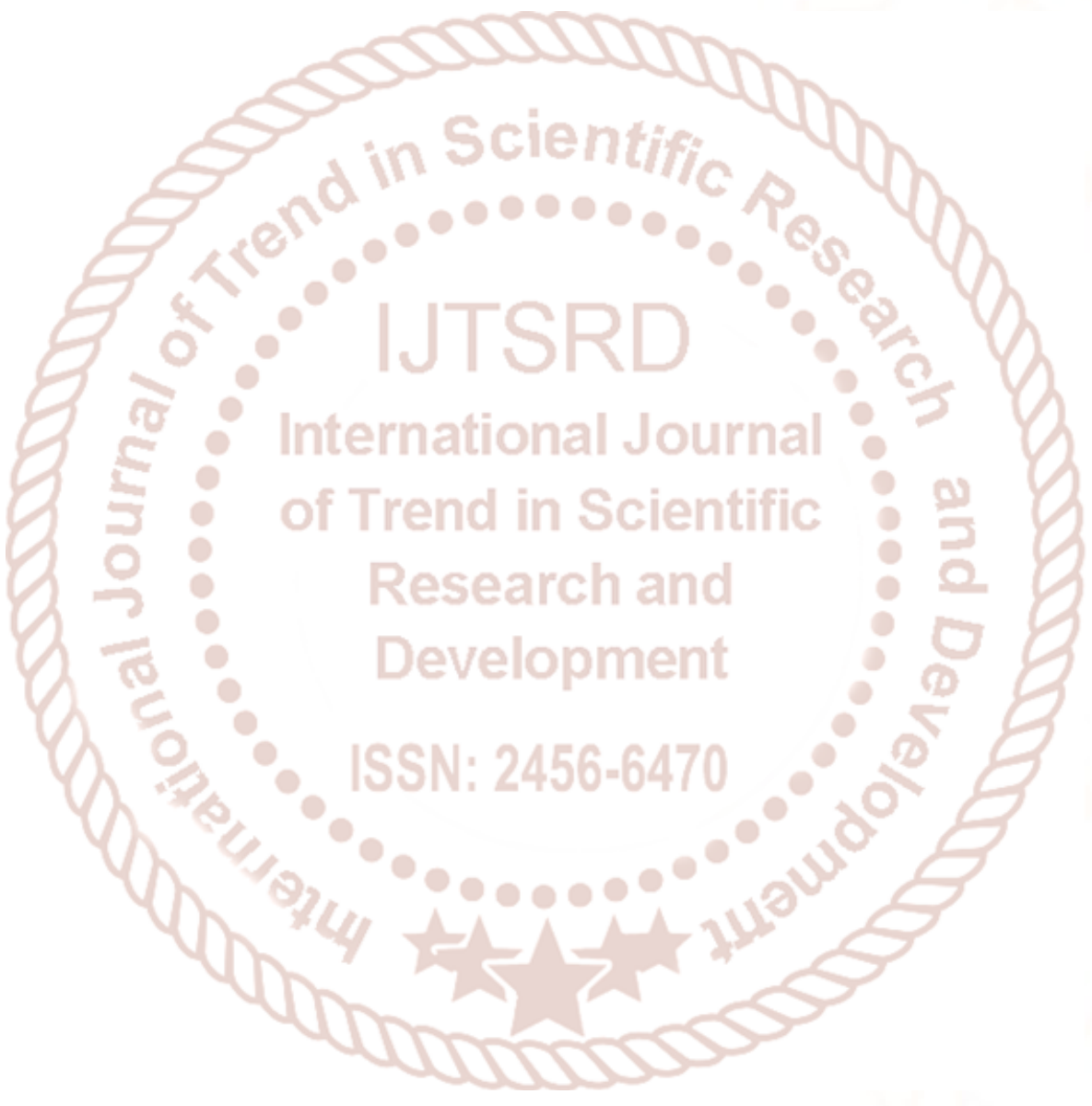

